\title{
Exploring the long-term Cenozoic Arctic Ocean climate history: a challenge within the International Ocean Discovery Program (IODP)
}

\author{
Ruediger Stein $^{1} \cdot$ Wilfried Jokat $^{1} \cdot$ Frank Niessen $^{1} \cdot$ Estella Weigelt $^{1}$
}

Received: 15 September 2015/Accepted: 20 October 2015/Published online: 20 November 2015

(C) Springer-Verlag Berlin Heidelberg 2015

\begin{abstract}
The global climate evolution during Cenozoic times is characterized by the transformation from warm Paleogene oceans with low latitudinal and bathymetric thermal gradients into the more recent modes of circulation characterized by strong thermal gradients, oceanic fronts, cold deep oceans, and cold high-latitude surface waters. Our understanding of this long-term Cenozoic climate history is mainly based on the continuous and high-resolution records from the low and mid-latitudes, whereas records from the high latitudes, especially the high northern latitudes, are strongly limited. From the central Arctic Ocean, information is restricted to sedimentary sections recovered on Lomonosov Ridge during the single scientific drilling campaign of the Integrated Ocean Drilling Program (IODP) in 2004 - the "Arctic Coring Expedition (ACEX)." By studying the unique ACEX sequence, a large number of scientific discoveries that describe previously unknown Arctic paleoenvironments have been obtained during the last decade. However, major key questions dealing with the Cenozoic climate history of the Arctic Ocean on its course from Greenhouse to Icehouse conditions remain unanswered. In this review paper, we present (1) the main highlights of the ACEX expedition and (2) why there is a need for further scientific Arctic drilling together with the plan, objectives and strategy for a drilling campaign on Lomonosov Ridge ("ACEX2"). ACEX2 is scheduled for 2018 as a mission-specific platform approach within the new International Ocean Discovery Program (IODP).
\end{abstract}

Ruediger Stein

Ruediger.Stein@awi.de

1 Alfred Wegener Institute Helmholtz Centre for Polar and Marine Research, Am Alten Hafen 26, 27568 Bremerhaven, Germany
Keywords Arctic Ocean - Cenozoic climate history · Scientific drilling · International Ocean Discovery Program

\section{Introduction and background}

In comparison with the other world oceans, the Arctic Ocean is unique because it is surrounded by the world's largest shelf seas, it is seasonally to permanently covered by sea ice and is characterized by large, strongly enhanced seasonal river discharge (Fig. 1; [2, 50]; for review see Stein [125]). The melting and freezing of sea ice result in distinct changes in surface albedo, energy balance, and biological processes. Freshwater and sea ice are exported from the Arctic Ocean through Fram Strait into the North Atlantic, and changes in these export rates of freshwater would result in changes of North Atlantic as well as global oceanic circulation patterns. Climate change in the Arctic may cause major perturbations in the global environment because of changes in sea ice cover and Earth's albedo system, which are important factors with respect to the global thermohaline circulation. Due to complex feedback processes (collectively known as "polar amplification"), the Arctic is both a contributor of climate change and the region that will be most affected by global warming [3, 4, 133]. The Arctic Ocean and surrounding areas thus are and have been subject to rapid and dramatic change. Over the last decades, for example, the extent and thickness of Arctic sea ice has decreased dramatically, which appears to be much more rapid than predicted by climate models (Fig. 1; e.g., [3, 4, 59, 111, 134, 135]).

Despite the importance of the Arctic Ocean in the global climate/earth system, however, this region is one of the last major physiographic provinces on Earth where the shortand long-term geological history is still poorly known 


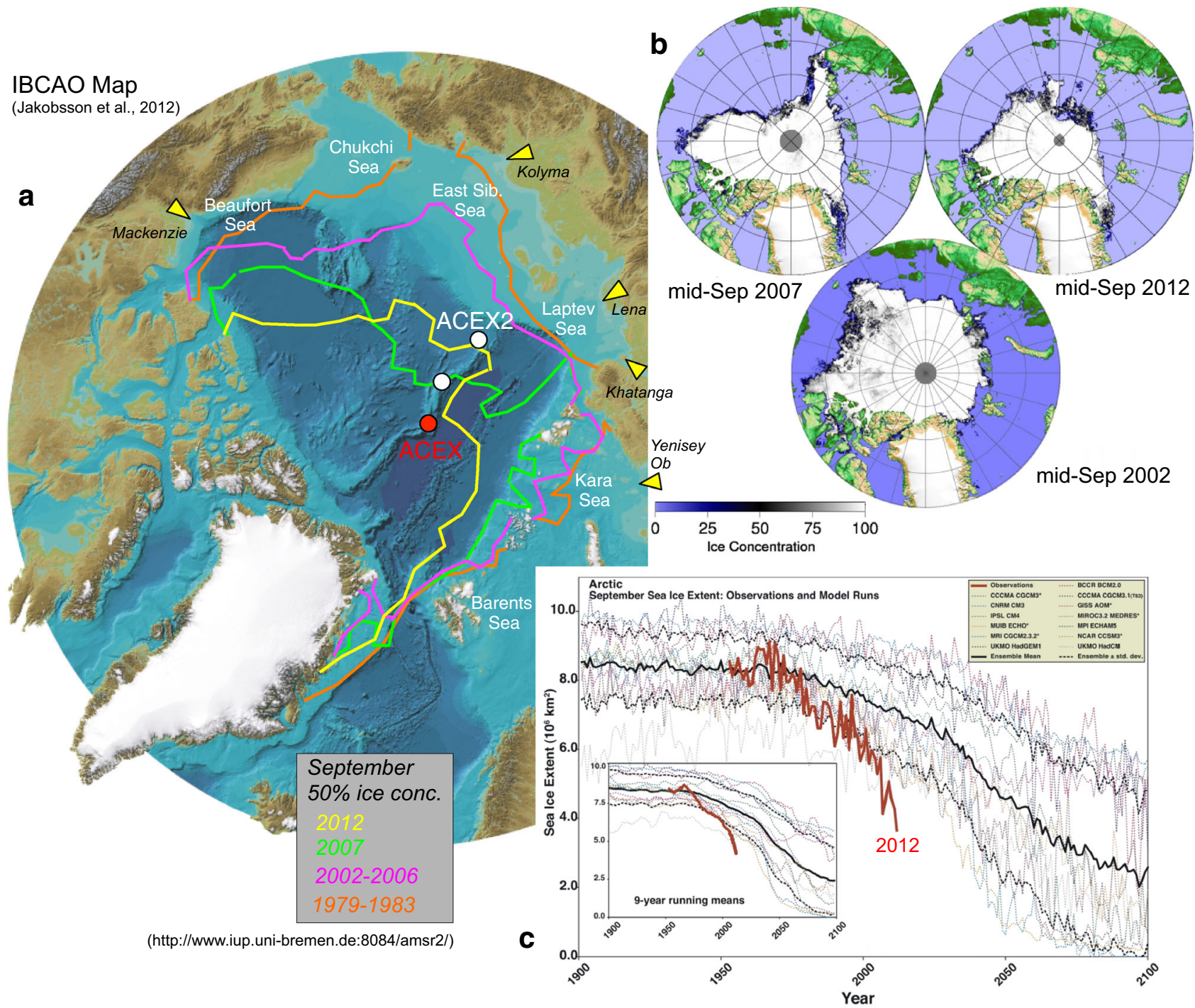

Fig. 1 a International bathymetric chart of the Arctic Ocean (IBCAO) [57] with limits of $50 \%$ sea ice concentration in September (orange: mean for 1979-1983, purple: mean for 2002-2006, green: 2007, and yellow: 2012; Source: http://www.iup.uni-bremen.de:8084/ amsr2/; cf., [119]. Yellow triangles mark discharge by the major Arctic rivers. ACEX and ACEX2 sites are indicated as red and white circles, respectively. b Maps showing the mid-September sea ice

(Fig. 2). This lack in knowledge is mainly due to the major technological/logistical problems in operating within the permanently ice-covered Arctic region which makes it difficult to retrieve long and undisturbed sediment cores. Prior to 1990, the available samples and geological data from the central Arctic Basins were derived mainly from drifting ice islands such as T-3 (e.g., Clark et al. [20] and CESAR [53]. During the last $\sim 30$ years, more than 30 expeditions with a geoscientific focus were carried out (Table 1), and numerous sediment cores were recovered from the main central Arctic Ocean ridges and basins (Fig. 3). Multidisciplinary studies of these sediment cores minimum concentrations for the years 2002, 2007, and 2012 (Source: http://www.iup.uni-bremen.de:8084/amsr2/; cf., [119]. c Arctic September sea ice extent $\left(\times 106 \mathrm{~km}^{2}\right)$ from observations (thick red line) and 13 IPCC AR4 climate models together with the multimodel ensemble mean (solid black line) and standard deviation (dotted black line). The absolute minimum of 2012 is highlighted (Fig. from [134, 135], supplemented)

have greatly advanced our knowledge on central Arctic Ocean paleoenvironment and its variability through Quaternary times. Prior to 2004, however, piston and gravity coring was mainly restricted to the upper $15 \mathrm{~m}$ of the sedimentary column. Thus, all studies were restricted to the late Pliocene/Quaternary time interval, with a few exceptions (Fig. 2). In four short cores obtained by gravity coring from drifting ice floes over the Alpha Ridge (for location see Fig. 3), older pre-Neogene organic carbon-rich mud and laminated biosiliceous oozes were sampled. These were the only samples recording the Late Cretaceous/early Cenozoic climate history and depositional environment 


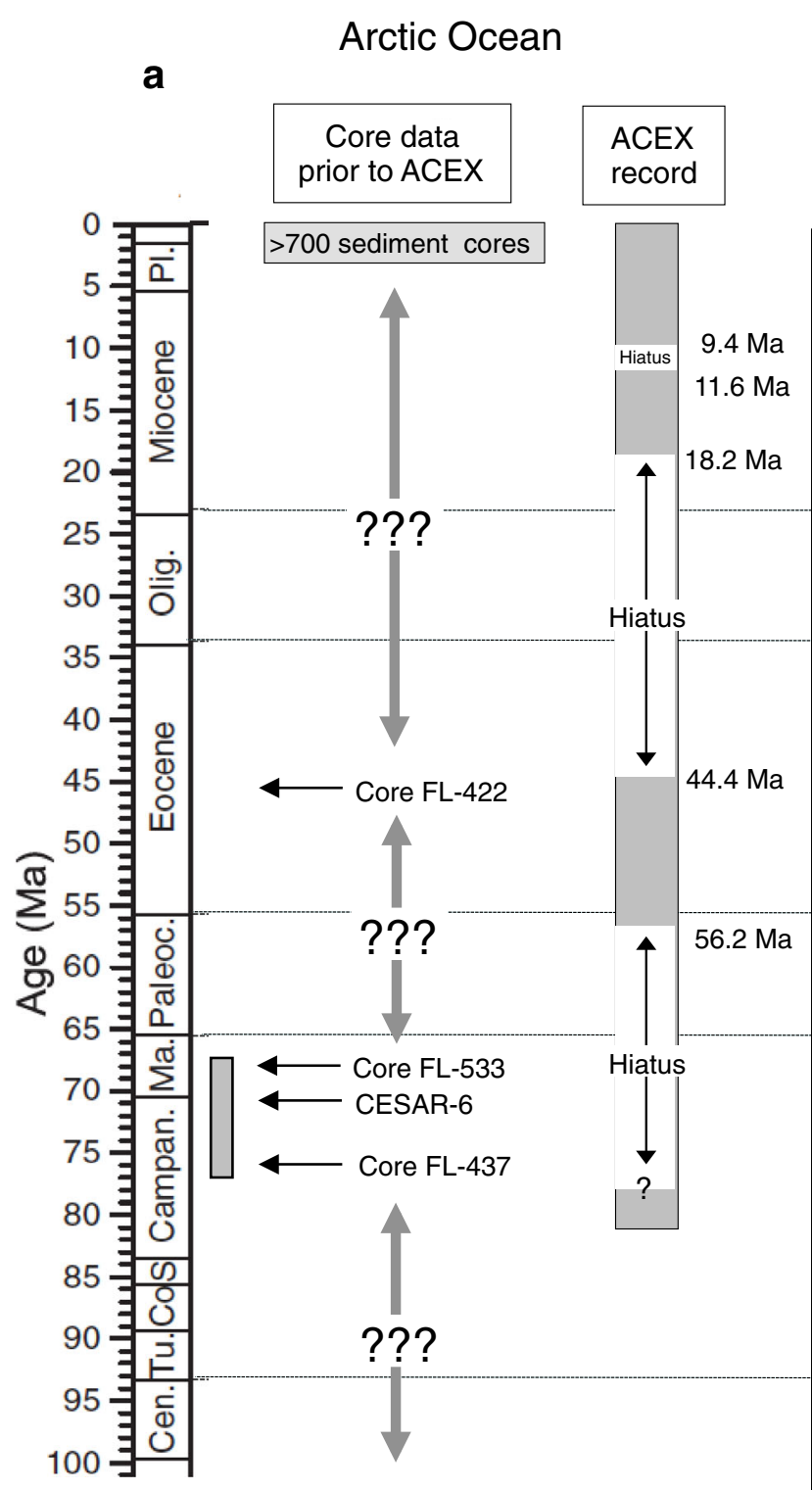

\section{b}

Global climate record

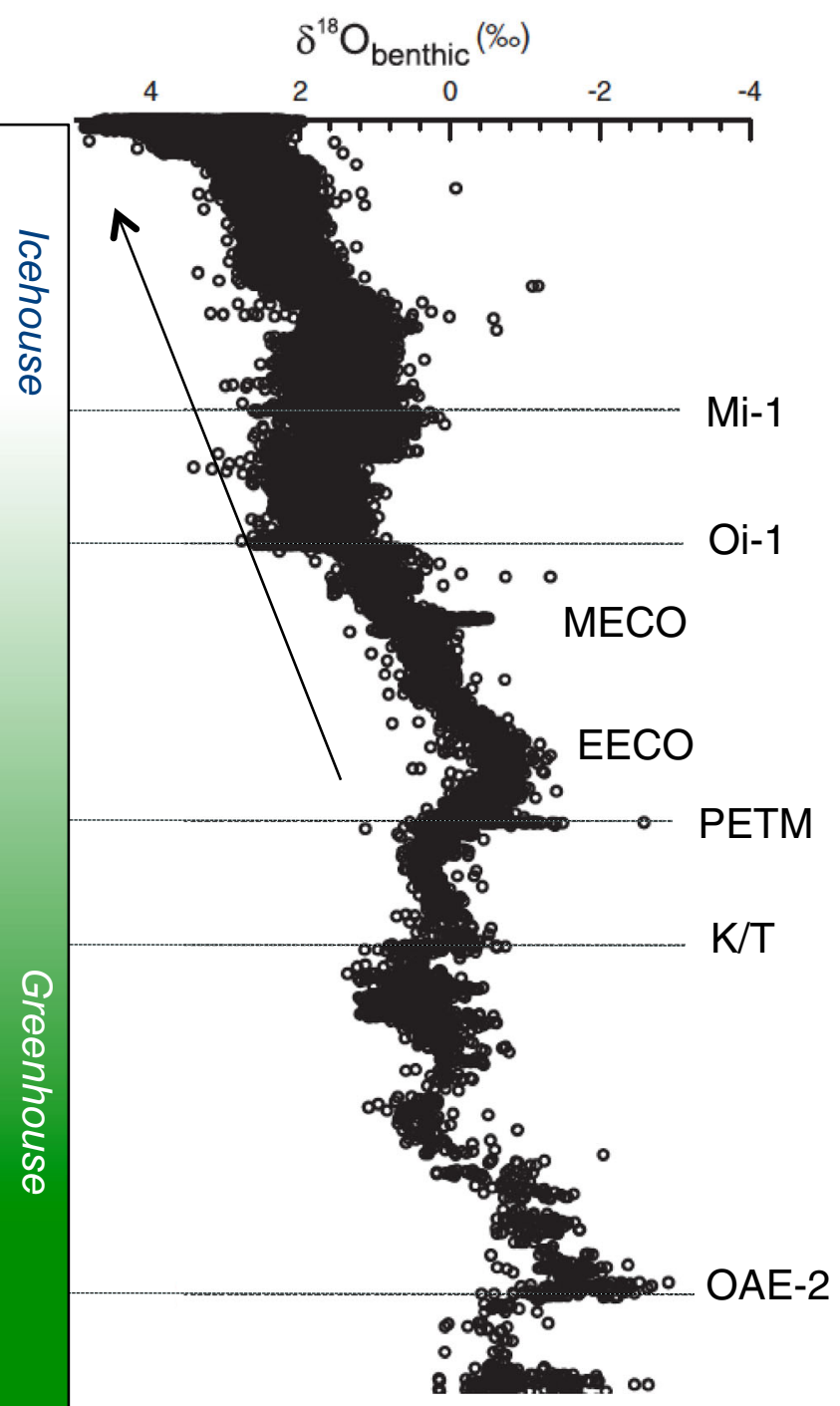

Fig. 2 a Stratigraphic coverage of existing sediment cores in the central Arctic Ocean prior to IODP-ACEX [140] and the section recovered during the ACEX drilling expedition $[8,13]$. The middle Eocene sediments recovered at Core FL-422 are arbitrarily placed at $45 \mathrm{Ma}$, the three late Cretaceous (Maastrichtian/Campanian) cores are arbitrarily placed on the time axis as well. Each of these four cores all recovered on Alpha Ridge (Fig. 3) documents a time period of at the most a few hundred kyrs [8]. b Global d180 stack of benthic

$[21,28,29,37,53,58]$. In general, these data suggest a warmer and ice-free Arctic Ocean with strong seasonality and high paleoproductivity. Continuous central Arctic Ocean sedimentary records, allowing a development of chronologic sequences of climate and environmental change through Cenozoic times and a comparison with global climate records (Fig. 2), were attempted to be acquired by the Integrated Ocean Drilling Program (IODP) foraminifera for the past 100 million years representing the greenhouse-icehouse transition [39]. $O A E-2$ Oceanic Anoxic Event 2, C/P Cretaceous/Paleogene Boundary, PETM Paleocene-Eocene Thermal Maximum, EECO Early Eocene Climate Optimum, MECO Middle Eocene Climate Optimum, $\mathrm{Mi}-1$ Major Miocene glaciation event, $\mathrm{Oi}$ 1 Major Oligocene glaciation event. "?" indicates time intervals not represented in Arctic Ocean sediment cores prior to the ACEX coring campaign in 2004

Expedition 302, the so-called Arctic Ocean Coring Expedition-ACEX [13, 88].

With the successful completion of ACEX in 2004, the first mission-specific platform (MSP) expedition within IODP, a new era in Arctic geoscientific research began. For the first time, scientific drilling in the permanently icecovered central Arctic Ocean was carried out, penetrating $428 \mathrm{~m}$ of Upper Cretaceous to Quaternary sediments on the 
Table 1 List of selected geoscientific icebreaker cruises to the Central Arctic Ocean

\begin{tabular}{|c|c|c|}
\hline Year of expedition and area & Ship and country & References (Cruise report or related paper) \\
\hline 1980 Nansen Basin, Yermak Plateau & Ymer (Sweden) & $\begin{array}{l}\text { Schytt et al. [15], Boström and Thiede } \\
\text { [110] }\end{array}$ \\
\hline 1987 Nansen Basin, Gakkel Ridge & Polarstern (Germany) & Thiede [137] \\
\hline 1991 Nansen/Amundsen Basin/Lomonosov Ridge & Oden/Polarstern (Sweden/Germany) & Andersen and Carlsson [5], Fütterer [41] \\
\hline 1993 Canada Basin/Chukchi Plateau & Polar Sea (USA) & Grantz et al. [43] \\
\hline 1993 Nansen Basin & Polarstern (Germany) & Fütterer [42] \\
\hline 1994 Transarctic (Canada Basin/Lomonosov Ridge) & $\begin{array}{l}\text { Polar Sea/Louis St. Laurent (USA/ } \\
\text { Canada) }\end{array}$ & Aagaard et al. [1], Wheeler [151] \\
\hline 1995 Amundsen/Makarov Basin/Lomonosov Ridge & Polarstern (Germany) & Rachor [102] \\
\hline 1996 Lomonosov Ridge/Makarov Basin & Oden (Sweden) & Backman et al. [9] \\
\hline 1997 Fram Strait/Yermak Plateau & Polarstern (Germany) & Stein and Fahl [127] \\
\hline 1998 Alpha Ridge/Lomonosov Ridge & Polarstern/Arktika (Germany/Russia) & Jokat [63], Jokat et al. [63] \\
\hline 2000 Mendeleev Ridge & Akademic Fedorov (Russia) & Kabańkov et al. [66] \\
\hline 2001 Nansen Basin/Gakkel Ridge (AMORE) & Healy/Polarstern (USA/Germany) & Thiede [138] \\
\hline 2001 Nansen Basin/Lomonosov Ridge & Oden (Sweden) & Grönlund [44] \\
\hline 2004 Yermak Plateau & Polarstern (Germany) & Stein $[122]$ \\
\hline 2004 Lomonosov Ridge (ACEX) & $\begin{array}{l}\text { Vidar Viking/Oden/Sovetskij Soyuz, } \\
\text { (IODP) }\end{array}$ & Backman et al. [13] \\
\hline 2005 Transarctic (HOTRAX) & Healy/Oden (USA/Sweden) & Darby et al. [27] \\
\hline $\begin{array}{l}2007 \text { Eur. Cont. Marg/Nansen Basin/Lomo-, Alpha } \\
\text { Ridge }\end{array}$ & Polarstern (Germany) & Schauer [108] \\
\hline 2007 Lomonosov Ridge off Greenland (LOMROG) & Oden/50 Let Pobedy (Sweden/Russia) & Jakobsson et al. [56] \\
\hline 2008 East Sib. Sea/Alpha-Mendeleev Ridge (AMEX) & Polarstern (Germany) & Jokat $[61]$ \\
\hline $\begin{array}{l}2011 \text { Eur. Cont. Marg/Nansen Basin/Lomo-, Alpha } \\
\text { Ridge }\end{array}$ & Polarstern (Germany) & Schauer [109] \\
\hline 2014 East Sib. Sea/Lomonosov Ridge (SWERUS) & Oden (Sweden) & Gustafsson and Jakobsson [45] \\
\hline 2014 Lomonosov Ridge (ALEX) & Polarstern (Germany) & Stein $[123]$ \\
\hline
\end{tabular}

This list is certainly not complete. Several other Arctic expedition were carried out during the last one to two decades, e.g., the six Chinese National Arctic Research Expeditions with the icebreaker XueLong in 1999, 2003, 2008, 2010, 2012 and 2014 and the five Korean Araon expeditions between 2010 and 2015 into the Bering Strait, Chukchi Borderland, Alpha-Mendeleev Ridge and Canada Basin area. In addition, there were numerous national and international expeditions carried out in the circum-Arctic marginal seas as well as the Norwegian-Greenland Sea including Fram Strait, all not listed here

crest of Lomonosov Ridge between 87 and $88^{\circ} \mathrm{N}$ (Fig. 4; [8, 11-13, 88]). The Lomonosov Ridge, a 1800-km-long continental fragment broken off of the Eurasian continental margin near $56 \mathrm{Ma}$ and separated by sea-floor spreading during the Cenozoic [60, 64, 65, 74], was identified as target area as the elevation of the ridge, $\sim 3 \mathrm{~km}$ above the surrounding abyssal plains, indicates that sediments on top of the ridge have been isolated from turbidites and are likely of purely pelagic origin (mainly biogenic, eolian, and/or ice-rafted). The ACEX coring sites were carefully selected based on comprehensive geophysical data sets, including seismic reflection profiles [63-65, 75], highresolution chirp profiles [55], and SCICEX swath bathymetry and sidescan sonar backscatter data [33]. Main objectives of the ACEX drilling campaign focused on the reconstruction of Cenozoic Arctic ice, temperatures, and climates. Some of the key questions to be answered from ACEX were framed around the evolution of sea ice and ice sheets, the past physical oceanographic structure, Arctic gateways, links between Arctic land and ocean climate, and major changes in depositional environments $[8,12,13]$. To date, the ACEX sites remain the only scientific deep sea drilling location in the central Arctic Ocean (Fig. 3).

This initial scientific drilling effort in the central Arctic Ocean was preceded by several workshops (Table 2) during which key scientific objectives as well as key areas for drilling were identified. Here, the science plan of NAD science committee [139] and the implementation plan of the Nansen Arctic drilling program [90] as well as the final report of the Ocean drilling program (ODP) "Arctic's role in GLOBAL climate change program planning group (APPG)" [51] deserve to be mentioned. This early phase of 
Fig. 3 Locations of gravity and piston cores from the Arctic Ocean [93], supplemented).

Green squares $=$ data

downloaded from http://www. geomapapp.

orgwww.geomapapp.org. White circles compiled data from icebreaker led expeditions during the past 30 years, added by locations of gravity cores recovered during the $2014 \mathrm{Po}$ larstern Expedition (red circles; [123]. Yellow circles ODP Leg 151 and IODP Exp 302/ACEX sites. Large redlined square indicates the area on the Alpha Ridge where short sediment cores with upper Cretaceous and Eocene sediments were recovered

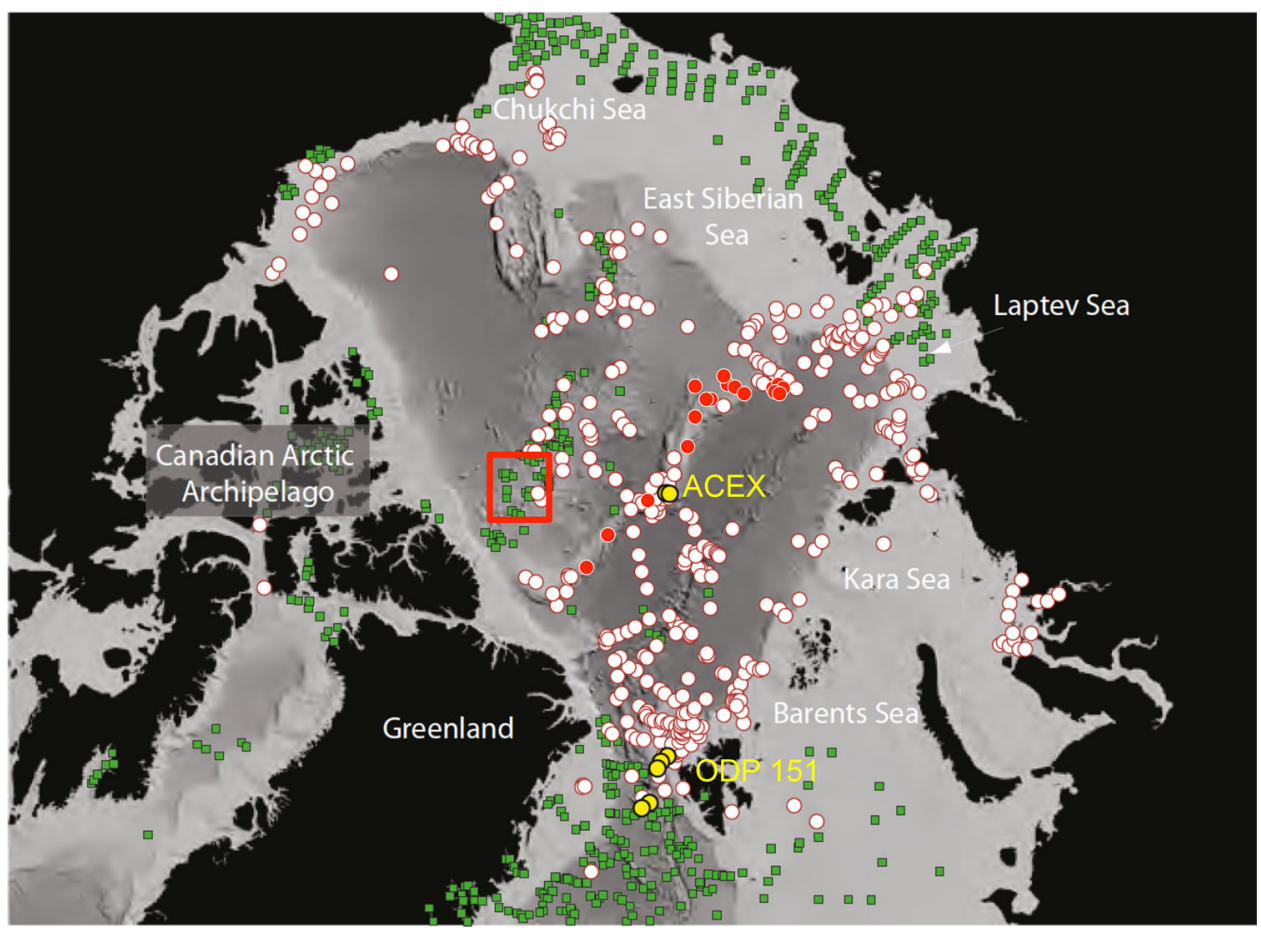

planning subsequently resulted in ODP/IODP Proposal 533 [7]; http://www.eso.ecord.org/docs/533.pdf) that went through the ODP/IODP review system between 1998 and 2003 (Table 3) and finally was scheduled as IODP Expedition 302 in 2004.

The present publication is composed of two parts. In the first part, highlights of the first IODP drilling campaign ACEX are summarized, mainly extracted from a recent review by Stein et al. [131]. In the second part, the need for further scientific Arctic drilling and the plan, objectives, and strategy of a future IODP drilling on Lomonosov Ridge scheduled for 2018 are outlined. This second part is mainly based on the IODP Proposal 708- "ACEX2" (Table 3; [130]).

\section{Highlights of the ACEX record}

The ACEX Cenozoic record holds significant scientific discoveries that describe previously unknown paleoenvironments $[11,12]$. Already the first results from some screening studies of the $>400$-m-thick sedimentary sequence, such as visual core description, smear-slide analyses, and total organic carbon (TOC) measurements [13, 124], suggest drastic paleoenvironmental changes through time. Whereas the upper half of the ACEX sequence (Subunits $1 / 1-1 / 4$ ) is composed of silty clay with very low TOC contents of $<0.5 \%$, i.e., values very similar to those known from upper Quaternary records determined in gravity cores from Lomonosov Ridge [125], the lower half of the ACEX sequence (Units 2-4) are characterized by high TOC values of 1 to $>5 \%$ (Fig. 5). In Subunit 1/5 (about 193-199 mcd) characterized by distinct gray/black color bandings ("Zebra Unit”), TOC maxima of 7-14.5\% were measured in samples from the black horizons [124].

By studying the unique sedimentary sequence recovered during ACEX in 2004, about 100 papers in highly ranked international peer-reviewed scientific journals have been published throughout the last decade. Key themes discussed in these papers are listed in Table 4. Some of the ACEX paleoceanographic themes and highlights with reference to the original literature are summarized here in some more detail (see also [11, 12, 125, 131]).

\section{The ACEX age model: still an open question}

A most important prerequisite of all types of paleoceanographic and paleoclimatic reconstructions is the development of precise chronologies. Backman's et al. [8] stratigraphic framework of the Cenozoic ACEX sequence, widely used in the scientific literature so far, is based on biostratigraphic, cosmogenic isotope, magneto- and cyclostratigraphic data. Based on age/depth control points, Neogene and Paleogene sedimentation rates reach values of about 1 and $2.4 \mathrm{~cm} \mathrm{ky}^{-1}$, respectively (Fig. 6). Although this ACEX age model may confirm that the average sedimentation rate mostly is $>1 \mathrm{~cm} \mathrm{ky}^{-1}$ (cf., [10]), a highly resolved and robust age model for the 


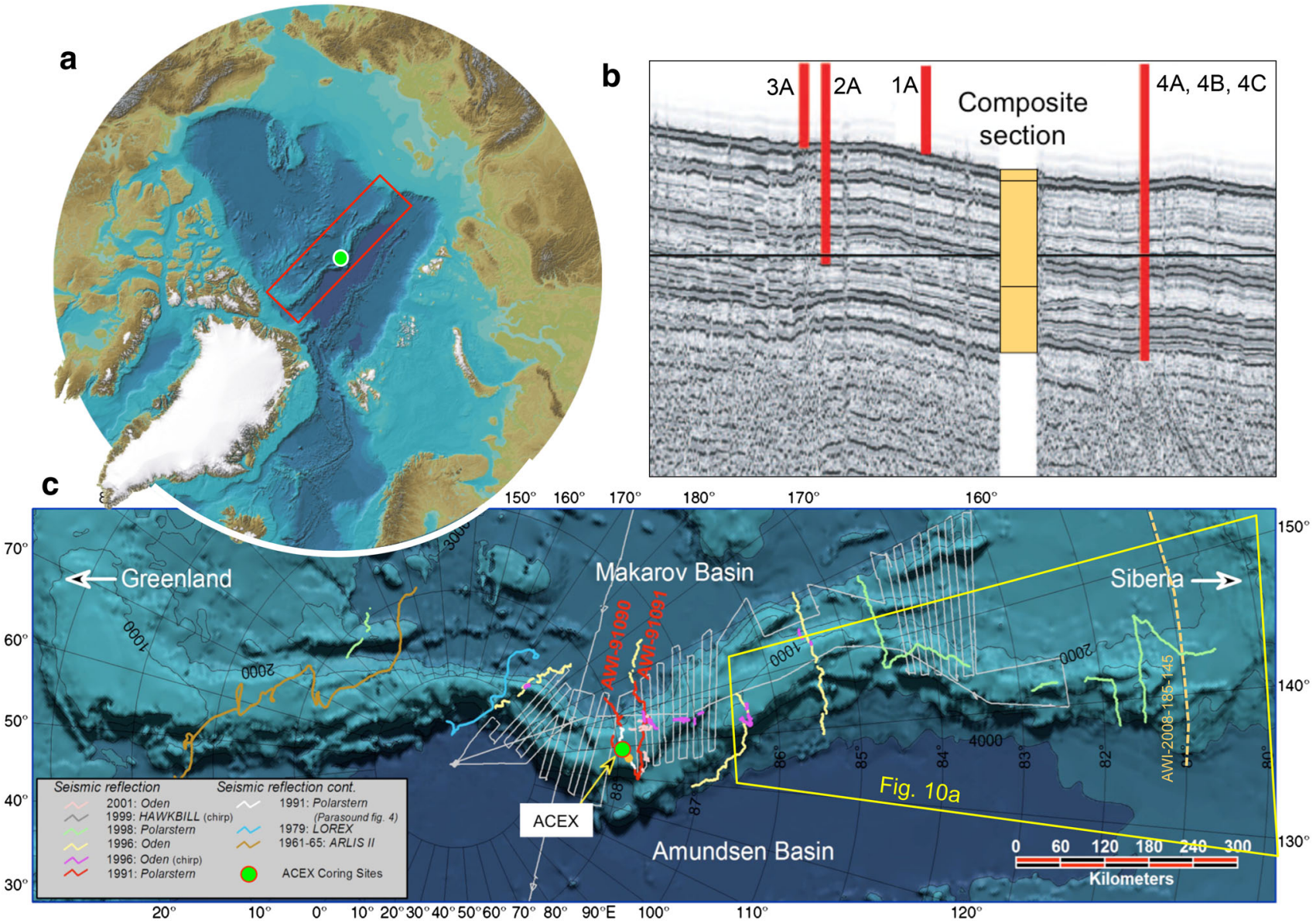

Fig. 4 a International bathymetric chart of the Arctic Ocean [57]. The ACEX site is shown as green circle, the redlined rectangle marks the area of Lomonosov Ridge shown in detailed in (c). b Seismic profile AWI 91090 across the Lomonosov Ridge, interpreted as continental crust truncated by a regional unconformity overlain by a continuous sediment sequence [64]. The four ACEX sites were positioned on this profile, shown as solid vertical lines. At each of the four sites (1-4), multiple holes $(A, B, C)$ were drilled, and a composite section has been obtained [13]. $\mathbf{c}$ The ACEX coring sites have been carefully selected based on comprehensive geophysical data sets, including seismic reflection profiles [63-65, 75], high-resolution chirp profiles [55], and SCICEX swath bathymetry and sidescan sonar backscatter data [33]. The area of Lomonosov Ridge shown in Fig. 11a is marked
Table 2 International workshops carried out for planning Arctic Ocean drilling
Arctic drilling workshop Halifax December 1986

Arctic drilling workshop Ottawa June 1988

First Nansen arctic drilling (NAD) meeting Washington DC, 1989

NAD workshop Stockholm 1990 (Thiede et al. [139])

NAD workshop St. Petersburg 1996 [90]

ODP PPG "Arctic's role in global change" [51]

JEODI Arctic drilling workshop Copenhagen 2003 [76]

Arctic drilling workshop Bremerhaven November 2008 [22]

Arctic drilling workshop Copenhagen November 2011 (Lead PI: N. Mikkelsen)

Arctic drilling workshop San Francisco December 2011 (Lead PI: C. Ruppel)

Arctic drilling workshop Kananaskis February 2012 (Lead PI: M. O’Regan)

Arctic drilling workshop Columbus/Ohio March 2013 (Lead PI: L. Polyak)

References for workshop reports or name of lead PI are listed in brackets 
Table 3 Steps of proposal submission and review of ACEX [7] and ACEX2 [130]

\begin{tabular}{|c|c|c|c|c|c|c|c|}
\hline \multicolumn{2}{|c|}{ ACEX submissions } & \multicolumn{2}{|c|}{ ACEX reviews } & \multicolumn{2}{|c|}{ ACEX2 submissions } & \multicolumn{2}{|c|}{ ACEX2 reviews } \\
\hline 533-Pre & $1998-03$ & SSEP & 1998-05 & 708-Pre1 & 2006-09 & SSEP & $2006-11$ \\
\hline 533-Full & 1999-03 & SSEP & 1999-05 & & & SSP & $2007-02$ \\
\hline \multirow[t]{3}{*}{ 533-Full2 } & $1999-10$ & SSEP & 1999-11 & 708-Pre2 & 2009-09 & SSEP & 2009-11 \\
\hline & & SSP & $2000-02$ & 708-Full & 2013-10 & SEP & 2014-01 \\
\hline & & External & $2000-02$ & & & External & 2014-02 \\
\hline 533-Add & $2000-03$ & SSEP & $2000-05$ & 708-PRL & 2014-02 & SEP & 2014-02 \\
\hline \multirow[t]{3}{*}{ 533-PRL } & $2000-04$ & SSP & $2000-07$ & & & EFB & 2014-03 \\
\hline & & SCICOM & $2000-08$ & & & SEP & 2014-06 \\
\hline & & SSP & 2001-02 & 708-Add & $2015-03$ & EFB & $2015-04$ \\
\hline \multirow[t]{2}{*}{ 533-PRL2 } & 2001-07 & SSP & 2001-07 & & & & \\
\hline & & SCICOM & 2001-09 & Acronym & Name of panel & Acronym & Name of panel \\
\hline \multirow[t]{7}{*}{ 533-Full3 } & $2002-03$ & iSSEP & $2002-06$ & SSEP & Science steering \& evaluation panel & SEP & Science evaluation panel \\
\hline & & iSSP & $2002-07$ & SSP & Site survey panel & EFB & ECORD facility board \\
\hline & & iPC & $2002-08$ & SCICOM & Science committee & External & $\begin{array}{l}\text { External review by experts } \\
\text { outside ODP/IODP }\end{array}$ \\
\hline & & iSSP & 2003-02 & iSSEP & $\begin{array}{l}\text { Interim science steering \& } \\
\text { evaluation panel }\end{array}$ & & \\
\hline & & iPPSP & 2003-06 & iSSP & Interim site survey panel & & \\
\hline & & iSSP & 2003-07 & iPC & Interim planning committee & & \\
\hline & & SPC & 2003-09 & iPPSP & $\begin{array}{l}\text { Interim pollution } \\
\text { prevention \& safety panel }\end{array}$ & & \\
\hline
\end{tabular}

ACEX cores is still challenging due to the poor core recovery (about 1/3 of the penetrated section was not recovered), the occurrence of an unexpected major hiatus, the limited availability of biostratigraphic indicators, and the enigmatic preservation of the geomagnetic polarity record [8]. Recently, Poirier and Hillaire-Marcel [101] report rhenium-osmium ( $\mathrm{Re}-\mathrm{Os}$ ) isochron ages and complementary Os-isotope measurements, together with new carbon and nitrogen data, that give information on the redox state of the sediment during deposition, and may allow a better assessment of the timing of events involved. Based on their new data, these authors also challenged the existing age model and the existence of a major hiatus between subunits $1 / 6$ and 1/5. That means, they proposed an improved age model that closes the gap in the ACEX record, resulting in a continuous sedimentary section with three to five times lower sedimentation rates (0.2-0.8 $\mathrm{cm} \mathrm{ky}^{-1}$ ) between about 49 and $12 \mathrm{Ma}$ (Fig. 6). The Os ages, of course, would significantly modify the reconstructions of the tectonic evolution of Lomonosov Ridge and the paleoceanographic history of the Arctic Ocean.

When using the Re-Os and organic carbon records, one should have in mind that these sediments contain significant amounts of reworked Eocene organic matter, on which the $\mathrm{Re}-\mathrm{Os}$ records are measured. The palynology confirms the presence of late Eocene and even Oligocene elements in Subunit 1/5 ("Zebra") [8, 105, 106]. However, the presumed in situ aquatic palynomorphs are $99 \%$ quasimonotypic assemblages of previously unknown dinocysts that have morphologic similarity with early Miocene ones [107]. This points to a restricted marine, or perhaps even freshwater setting, extremely unlikely to have occurred during the Eocene or even Oligocene [105]. Furthermore, there are also massive geochemical breaks in this section that may point to discontinuous sedimentation [105, 106]. More long sedimentary records from the Arctic Ocean are needed to resolve these issues and related paleoenvironmental reconstructions.

\section{Prominent paleogene events of anoxia: PETM event, elmo event, and azolla event}

The Paleocene/Eocene Thermal Maximum (PETM) event, a relatively brief period of widespread, extreme climatic warming [71, 104, 144, 155, 156], and probably associated with massive atmospheric greenhouse gas input [31], was identified in the ACEX record by the occurrence of the dinocyst species Apectodinium augustum, which is diagnostic of the PETM [19], as well as a distinct negative anomaly in $\delta 13$ Corg (Fig. 7) [98, 116, 117, 128]. During the PETM event, the Arctic Ocean surface water temperatures reached maximum values around $25^{\circ} \mathrm{C}$ as reconstructed from TEX86 data [116, 117]. These are values 


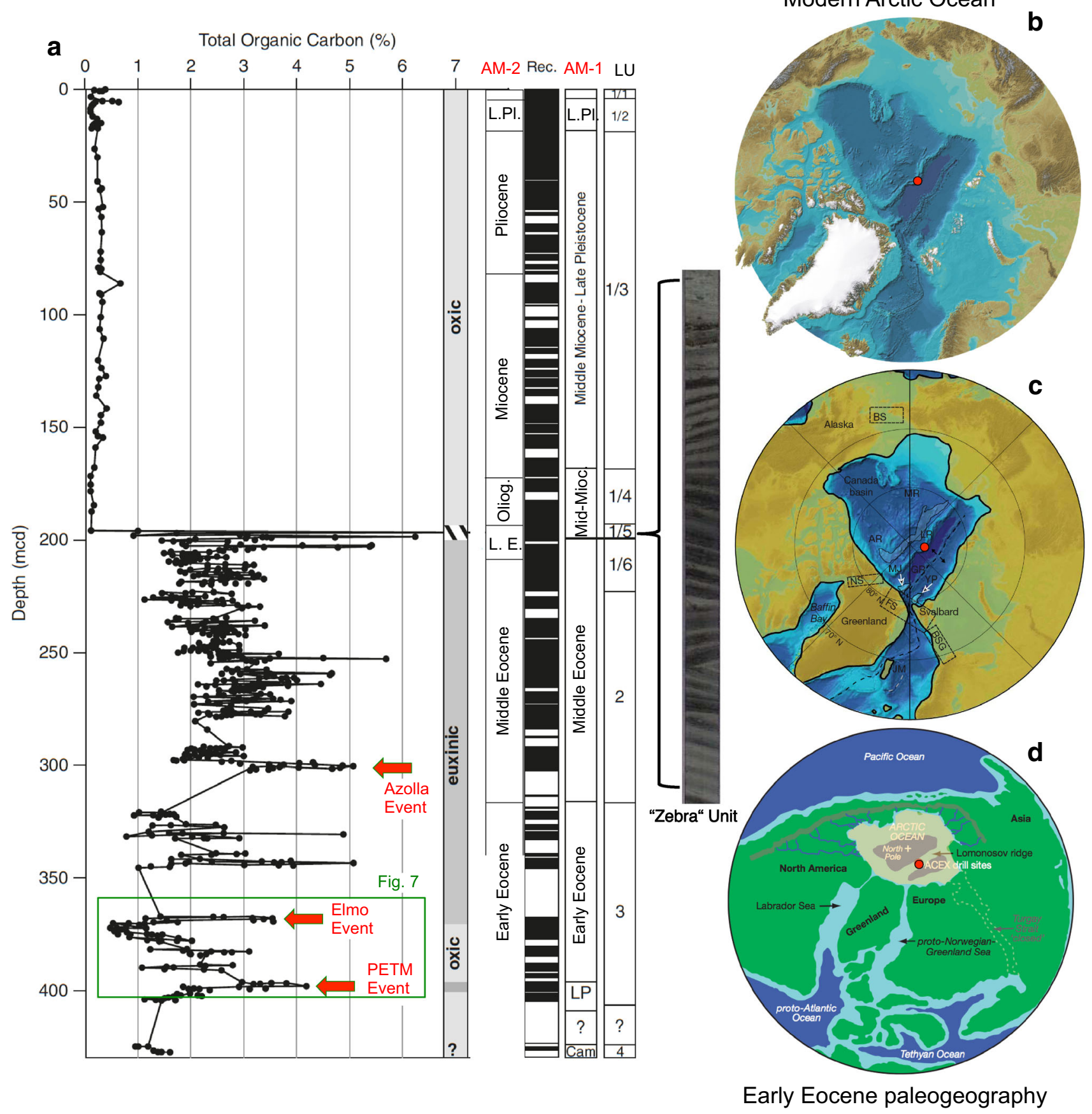

Fig. 5 a Record of total organic carbon (TOC) contents as determined in the composite ACEX sedimentary sequence [124]. Data on lithological units (LU) and core recovery (Rec.) from Backman et al. [13]. The "Zebra" Unit (Unit 1/5) marks the transition between an euxinic ocean and an oxygenated ocean that occurred when the formerly isolated Arctic Ocean became connected to the world ocean via Fram Strait (Fig. 5c). Cam Campanian, LP late Paleocene, Mid Mioc. middle Miocene, L.Pl. late Pleistocene. PETM, Elmo (ETM2), and Azolla events are indicated. Age models AM-1 [8] and AM-2 [101] are shown (cf., Fig. 6). For more details and data of the PETM-Elmo time intervals see Fig. 7. b International
Bathymetric Chart of the Arctic Ocean [57] representing modern boundary conditions with connections to the world ocean. c Paleogeographic/paleobathymetric reconstruction for the late early Miocene. $B S G$ Barents Sea Gateway, $J M$ Jan Mayen Microcontinent, $K R$ Knipovich Ridge, $M J$ Morris Jessup Rise, $N S$ NaresStrait, $Y P$ Yermak Plateau [54], supplemented). d Paleogeography of the Arctic region for the early-middle Eocene during the phase of biosilica production and preservation and euxinic conditions (50-45 Ma) [18, 132]. The ACEX drill site is marked as red circle. "?" indicates uncertainties in the stratigraphy 
Table 4 Main research themes and related papers of ACEX

\begin{tabular}{|c|c|}
\hline ACEX objective/topic & References \\
\hline Stratigraphy and chronology & $\begin{array}{l}\text { Backman et al. [8], Frank et al. [38], O’Regan et al. [94], Matthiessen et al. [83], Kaminiski } \\
\text { et al. [68], Onadera and Takahashi [95, 96], Poirier and Hillaire-Marcel [100, 101], } \\
\text { Sangiorgi et al. [107], Setoyama et al. [112] }\end{array}$ \\
\hline $\begin{array}{l}\text { Description and analysis of microfossil } \\
\text { assemblages }\end{array}$ & $\begin{array}{l}\text { Eynaud et al. [36], Kaminiski et al. [68], Onadera et al. [97], Onadera and Takahashi [95, 96], } \\
\text { Setoyama et al. [112], Suto et al. [136], Matthiessen et al. [83, 84], Sangiorgi et al. [107] }\end{array}$ \\
\hline $\begin{array}{l}\text { Subtropical warm conditions during PETM and } \\
\text { the early-middle Eocene }\end{array}$ & $\begin{array}{l}\text { Sluijs et al. [116, 117], Weijers et al. [149], Weller and Stein [150], Ogawa et al. [92], Stein } \\
\text { et al. [131] }\end{array}$ \\
\hline $\begin{array}{l}\text { Arctic Ocean hydrological cycle during the } \\
\text { Paleogene }\end{array}$ & Brinkhuis et al. [18], Pagani et al. [98], Waddell and Moore [147] \\
\hline $\begin{array}{l}\text { Black shales and euxinic conditions in the } \\
\text { Eocene Arctic Ocean }\end{array}$ & Moran et al. [88], Stein et al. [128, 131], Stein [124], Knies et al. [72], Mann et al. [81] \\
\hline $\begin{array}{l}\text { Orbital forcing and environmental response } \\
\text { during the Paleogene }\end{array}$ & Pälike et al. [99], Sangiorgi et al. [106], Spofforth et al. [120] \\
\hline $\begin{array}{l}\text { Early onset of Arctic sea ice and NHG in the } \\
\text { middle Eocene }\end{array}$ & Moran et al. [88], St. John [121], Stickley et al. [132], Immonen [52] \\
\hline $\begin{array}{l}\text { Early (Miocene/Eocene) Arctic perennial versus } \\
\text { seasonal sea ice }\end{array}$ & $\begin{array}{l}\text { Darby [25, 26], Krylov et al. [77], Matthiessen et al. [83, 84], Kender and Kaminski [69], } \\
\text { Stein et al. [131], Trembley et al. [143] }\end{array}$ \\
\hline $\begin{array}{l}\text { Arctic gateway evolution and circulation } \\
\text { changes }\end{array}$ & Jakobsson et al. [54], Kaminski et al. [68] \\
\hline Neogene paleoenvironmental changes & Cronin et al. [23], Haley et al. [46], Eynaud et al. [36], Matthiessen et al. [83, 84] \\
\hline $\begin{array}{l}\text { Tectonic/subsidence history of Lomonosov } \\
\text { Ridge }\end{array}$ & Moore et al. [87], O’Regan et al. [94] \\
\hline
\end{tabular}

significantly higher than previous estimates of $10-15^{\circ} \mathrm{C}$ [146] and model predictions [114, 142], indicating a distinctly lower equator-to-pole temperature gradient than previously believed [116].

With the PETM event, a drastic change in TOC content and composition of organic carbon (OC) is obvious, pointing to a prominent change in the environmental conditions (Fig. 7). Terrigenous OC is predominant in the late Paleocene, whereas the amount of labile OC significantly increased across the PETM as indicated by increased hydrogen index values as well as increased preservation of algae-type biomarkers [125, 131, 150]. The increased preservation of labile algae-type OC is related to a major change to euxinic conditions, as indicated by a drastic decrease in the $\mathrm{C} / \mathrm{S}$ values, the occurrence of pyrite framboids [128], the absence of benthic foraminiferal linings [116], and the occurrence of fine lamination [13]. During the PETM, euxinic conditions expanded even into the photic zone as suggested from the occurrence of the biomarker isorenieratene related to photosynthetic green sulfur bacteria which requires euxinic conditions to thrive $[115,116,150]$. Toward the end of the PETM event in the earliest Eocene, a gradual return to a more terrestrial influence is obvious and oxic conditions reoccurred as clearly reflected in all geochemical proxies (Fig. 7).
Within the lower Eocene section of the ACEX sequence (at about $368 \mathrm{mcd}$ ), an event with similar characteristics as the PETM event was identified for the first time by Stein et al. [128] based on a prominent $\delta 13$ Corg minimum (Fig. 7). This event may correlate with the global "Elmo (or ETM2) Event" representing a second (smaller) global thermal maximum [80]. In the ACEX record, this interval is characterized by significantly increased OC contents mainly composed of labile algae-type organic matter, as reflected in Rock-Eval data and biomarker composition. Furthermore, low $\mathrm{C} / \mathrm{S}$ ratios $(<1)$ point to an euxinic environment permitting the preservation of the labile $\mathrm{OC}$ (Fig. 7; [128, 150]).

The lowermost middle Eocene OC-rich section of the ACEX sequence (about 299-305 mcd; Fig. 5), representing the time interval between about 49 and $48.3 \mathrm{Ma}$, are composed of microlaminated sediments with extraordinary abundances of microspore clusters (massulae) of the freefloating freshwater fern Azolla [18]. Azolla is typically known from modern freshwater bodies, such as ponds, canals and flooded rice paddies in tropical, subtropical, and warm temperate regions, and cannot tolerate salinities higher than 1-1.6\% [6, 103]. Based on (1) the presence of mature megaspores with and without attached massulae, (2) single, small groups, and large clusters of massulae and probable aborted megaspores of Azolla, and (3) support by 


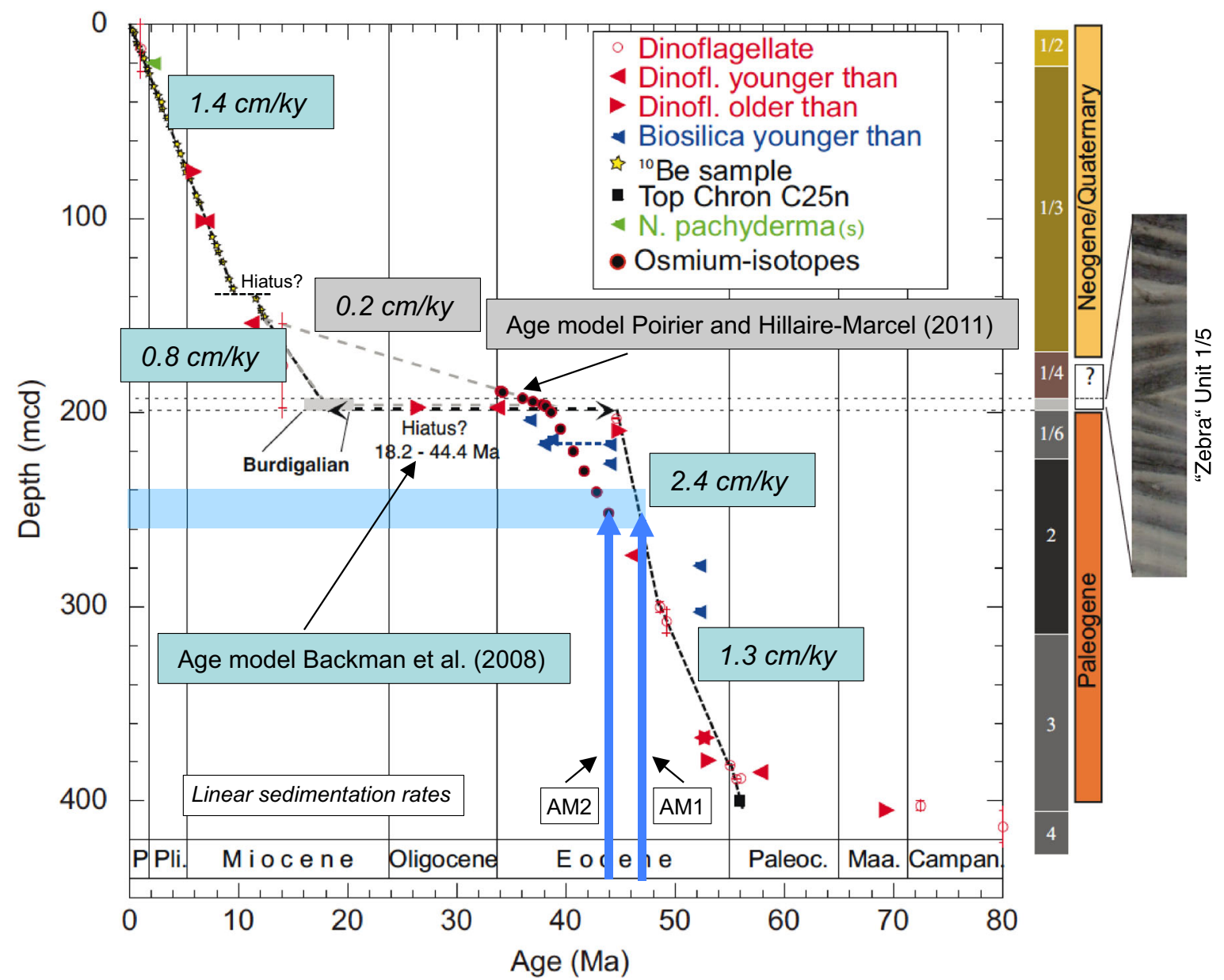

Fig. 6 Age/depth diagram and main lithological units of the ACEX section [93], supplemented, based on the biostratigraphically derived age model by Backman et al. [8]. The alternate chronology based on osmium isotopes [101] is also shown. Depth of first occurrence of IRD between 240 and 260 mcd are marked as light blue horizontal

the relative scarcity of terrestrially derived palynomorphs and extremely low BIT index values of $<0.1$ (indicating low river-derived terrestrial organic matter), Brinkhuis et al. [18] favor the idea that Azolla grew and reproduced in situ in the Arctic Ocean rather than being brought in by periodic mass transport from freshwater bodies on adjacent continents. That is to say, the Azolla event probably represents a distinct episodic freshening of Arctic surface waters lasting about 700-800 kyrs [14, 24, 118]. The freshening of surface waters supports stratification of water masses, causing the euxinic conditions reflected in the $\mathrm{C} / \mathrm{S}$ diagram, with $\mathrm{C} / \mathrm{S}$ ratios $<1[128,131]$.

\section{Early onset of Arctic sea ice formation and cooling of sea surface temperatures}

From subarctic ice-rafted debris records in the NorwegianGreenland Sea, Iceland Sea, and Irminger Sea and Fram bar. The different ages of the first occurrence of IRD, obtained by the two age models-AM1 = Backman et al. [8], AM2 = Poirier and Hillaire-Marcel [101] —are indicated by the blue arrows. Mean sedimentation rates $(\mathrm{cm} / \mathrm{ky})$ are indicated. Figure from O'Regan [93], supplemented. "?" indicates uncertainties in the stratigraphy

Strait area, it has been indirectly inferred that the Northern Hemisphere Glaciation (NHG) began at about $14 \mathrm{Ma}[40$, 141, 152, 153]. Glaciation of Antarctica, on the other hand, began much earlier, with large ice sheets first appearing near the Eocene/Oligocene boundary at about $34 \mathrm{Ma}[35$, $70,79,85,86,113,155,156]$. The ACEX results, however, push back the date of Northern Hemisphere cooling and onset of sea ice into the Eocene as well. The first occurrence of sea ice-related diatoms, contemporaneously with IRD, was at about 47-46 Ma (when using the ACEX age model of Backman et al. [8]; "Age Model 1") or $\sim 43 \mathrm{Ma}$ (when using the alternate chronology of Poirier and Hillaire-Marcel [101]; “Age Model 2") (Fig. 8). Iceberg transport was probably also present in the middle Eocene, as indicated by mechanical surface texture features on quartz grains from this interval $[121,132]$. An early onset/ intensification of NHGs during Eocene times is also supported by IRD records from the Greenland Basin ODP Site 


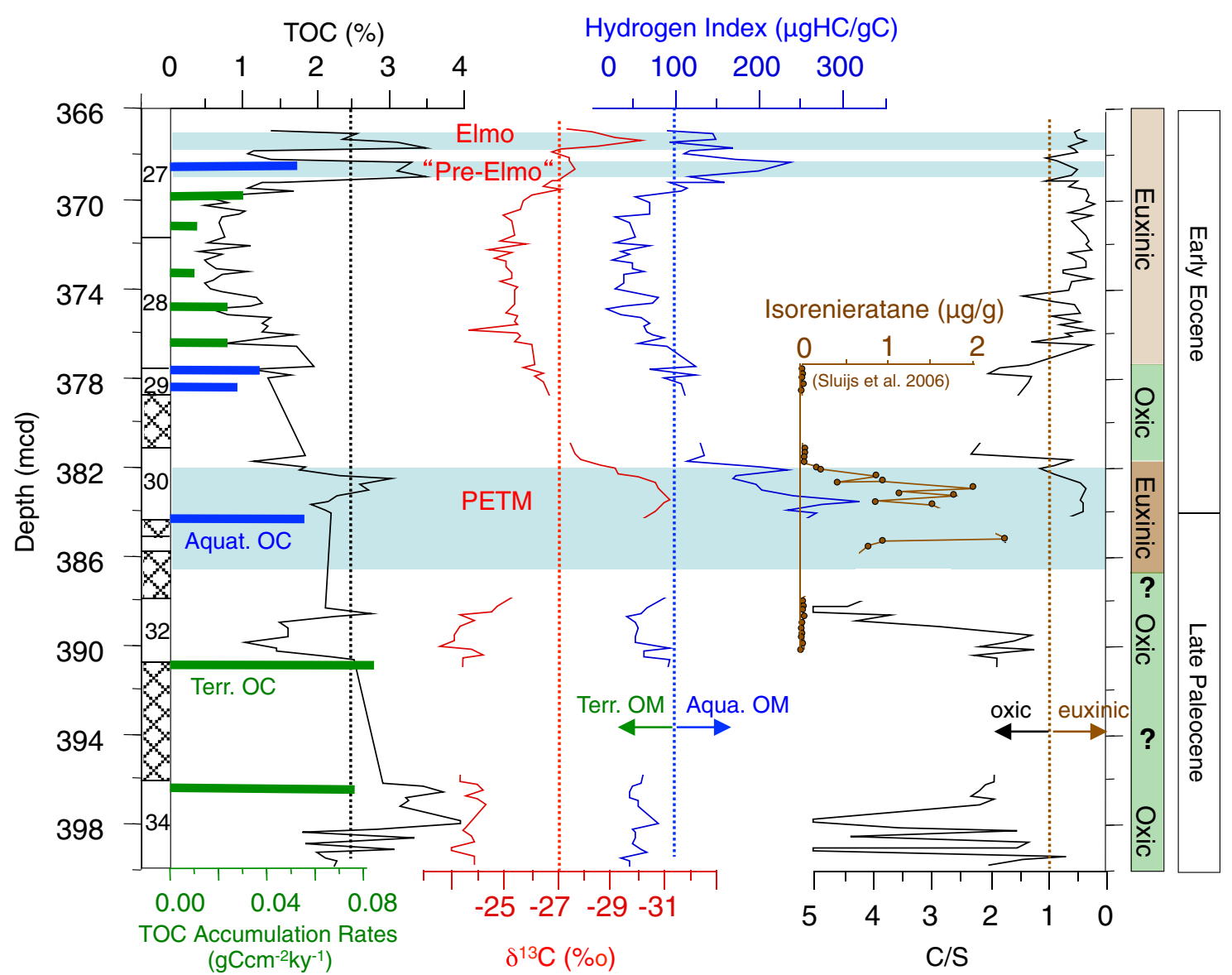

Fig. 7 TOC contents, TOC accumulation rates (green bars: terrigenous organic matter; blue bars: aquatic/marine organic matter), $\delta 13 \mathrm{C}$ of the organic matter, hydrogen index values obtained by Rock-Eval pyrolysis, and $\mathrm{C} / \mathrm{S}$ values with interpretation in terms of euxinic versus oxic conditions for the earliest Eocene/late Paleocene time interval of the ACEX reord, including the PETM and Elmo events $[128,129]$. The $\delta 13$ Corg Elmo Event is probably preceded by another

913 [34, 145]. These findings suggest that Earth's transition from the Greenhouse to the Icehouse world was bipolar, which points to greater control of global cooling linked to changes in greenhouse gases in contrast to tectonic forcing [8, 13, 30, 88, 132].

The cooling trend and onset of sea ice formation recorded in the ACEX record, coinciding with the global post-EECO cooling trend [156], are also reflected in the ACEX sea surface temperature (SST) (Fig. 8;

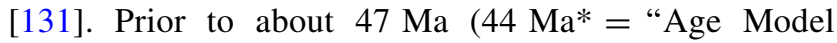
2 "), warm SST values between 18 and $26^{\circ} \mathrm{C}$ were predominant, interrupted by a prominent, short-lived cooling to $5-10{ }^{\circ} \mathrm{C}$ event near $47.3 \mathrm{Ma}$ (44.5 Ma*). At about 46.3 Ma (41.5 $\left.\mathrm{Ma}^{*}\right)$, summer SST dropped down to $<17{ }^{\circ} \mathrm{C}$ (range $8-17^{\circ} \mathrm{C}$ ), coinciding with a significant increase in ice-rafted debris (IRD) [121, 132]. An absolute SST minimum of $6-8{ }^{\circ} \mathrm{C}$ was reached at about 44.8 Ma (37.8 Ma), followed by a short but prominent warm phase with a SST around $17^{\circ} \mathrm{C}$ near $44.6 \mathrm{Ma}$ distinct (euxinic) event of increased preservation of algae-type OC (or can be divided into two subevents). In addition, the occurrence of the biomarker isorenieratene across the PETM Event is shown [116]. The numbers 27-34 at the left-hand side are core numbers, crossed intervals are coring gaps. "?" indicates intervals where classification "oxic vs. euxinic" is not possible due to missing data/samples

(37.5 $\left.\mathrm{Ma}^{*}\right)$. This warming event is characterized by the absence of IRD (Fig. 8), interpreted to reflect lack of sea ice. Apart from this warm event, however, widespread sea ice seems to be the more typical phenomenon of the Arctic Ocean after about $45.5 \mathrm{Ma}$ (40.5 Ma*) (Fig. 8).

Overall, the Arctic SST values remain surprisingly high, even in the upper part of our ACEX record. The apparent paradox of coincidence of such a warm SST and sea ice, however, can be explained. Assuming that the alkenone SST represents rather the summer SST and considering the strong seasonal temperature variability of $>10{ }^{\circ} \mathrm{C}$ during the early-middle Eocene (see above), favorable conditions for sea ice formation may have occurred during winter time. That means, after about $46.3 \mathrm{Ma}$ (41.5 Ma*) the environmental conditions in part of the Arctic Ocean might have been similar to that observed in the modern Baltic Sea where summer SSTs of $>15^{\circ} \mathrm{C}$ and winter SSTs $<1{ }^{\circ} \mathrm{C}$ with sea ice formation are typical $[73,154]$. 


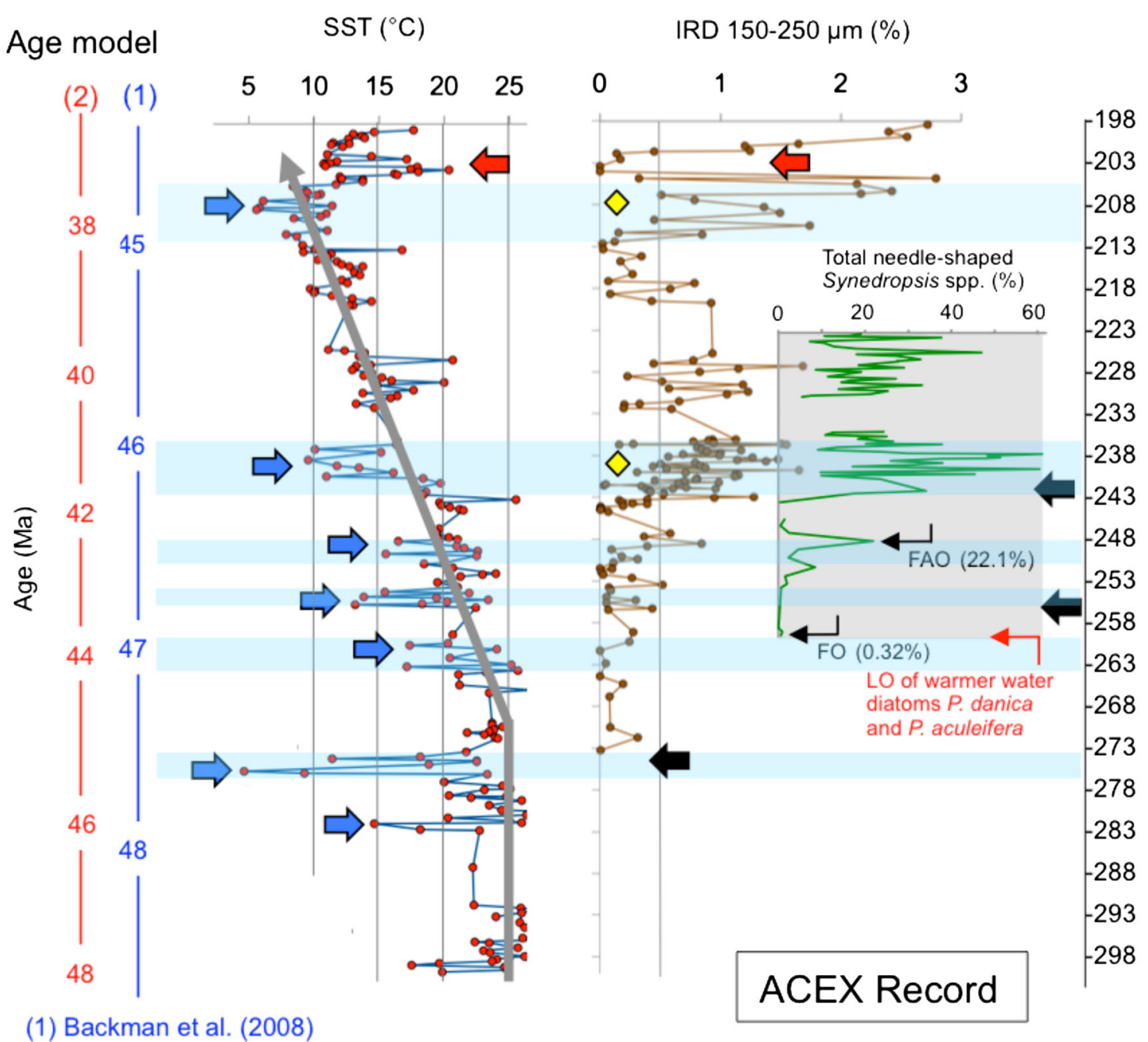

(2) Poirier and Hillaire-Marcel (2011)

Fig. 8 Alkenone-based sea surface temperature (SST) [131] and abundance of ice-rafted debris (IRD) [121], determined in the ACEX sequence from 298 to $198 \mathrm{~m}$ below seafloor (mcd). For the ACEX interval 260-223 mcd, the abundance of sea ice diatom species Synedropsis spp. is also shown [132]. In the diatom record, the first occurrence (FO) and abundant occurrence (FAO) of the sea ice species and the last occurrence (LO) of warmer water diatoms Porotheca danica and Pterotheca aculeifera are also shown. The two

In contrast to our interpretation, Darby [26] postulated ephemeral formation of even perennial sea ice in the Arctic Ocean during the middle Eocene. This statement is based on the occurrence of specific coarse Fe grains (IRD) with a distal source area that has a $>1$-year drift time to the ACEX core site. The onset of deposition of such Fe grains at the ACEX site is almost contemperaneous with the drop in SST as well as the onset of IRD, sea ice diatoms, and C37:4 alkenones [131]. The latter data, however, are more indicative for a seasonal sea ice cover. Thus, if present, phases of perennial sea ice should have been more the exception in the middle Eocene, whereas seasonal sea ice yellow rhombs in the IRD record indicate occurrence of large-sized single dropstones [88]. Large blue arrows and light blue horizontal bars indicate major cooling events; the large red arrows highlight a major warming event near 44.6 Ma. Large black arrows indicate major steps/increases in sea ice cover. On the left-hand side, the two different age scales discussed in the text, are shown; Age Model 1 [8] and Age Model 2 [101]

should have been the rule. Based on the simulation of icedrift pattern and velocities under permanent and seasonal ice conditions, Trembley et al. [143] challenged Darby's approach and also support a seasonal Arctic Ocean sea ice cover.

\section{From an euxinic "lake stage" to a fully ventilated "ocean phase"}

Black OC-rich, partly finely laminated, biosiliceous silty clays and clayey silts were found throughout the upper lower to middle Eocene of the ACEX record, indicating 
Fig. 9 Active IODP proposals for drilling in the Arctic Ocean. From the seven proposals, only Proposal 708-Full is ready to go and scheduled for 2018. For each proposal, main area/key theme and lead PI are listed. SEP Science Evaluation Panel, EFB ECORD Facility Board

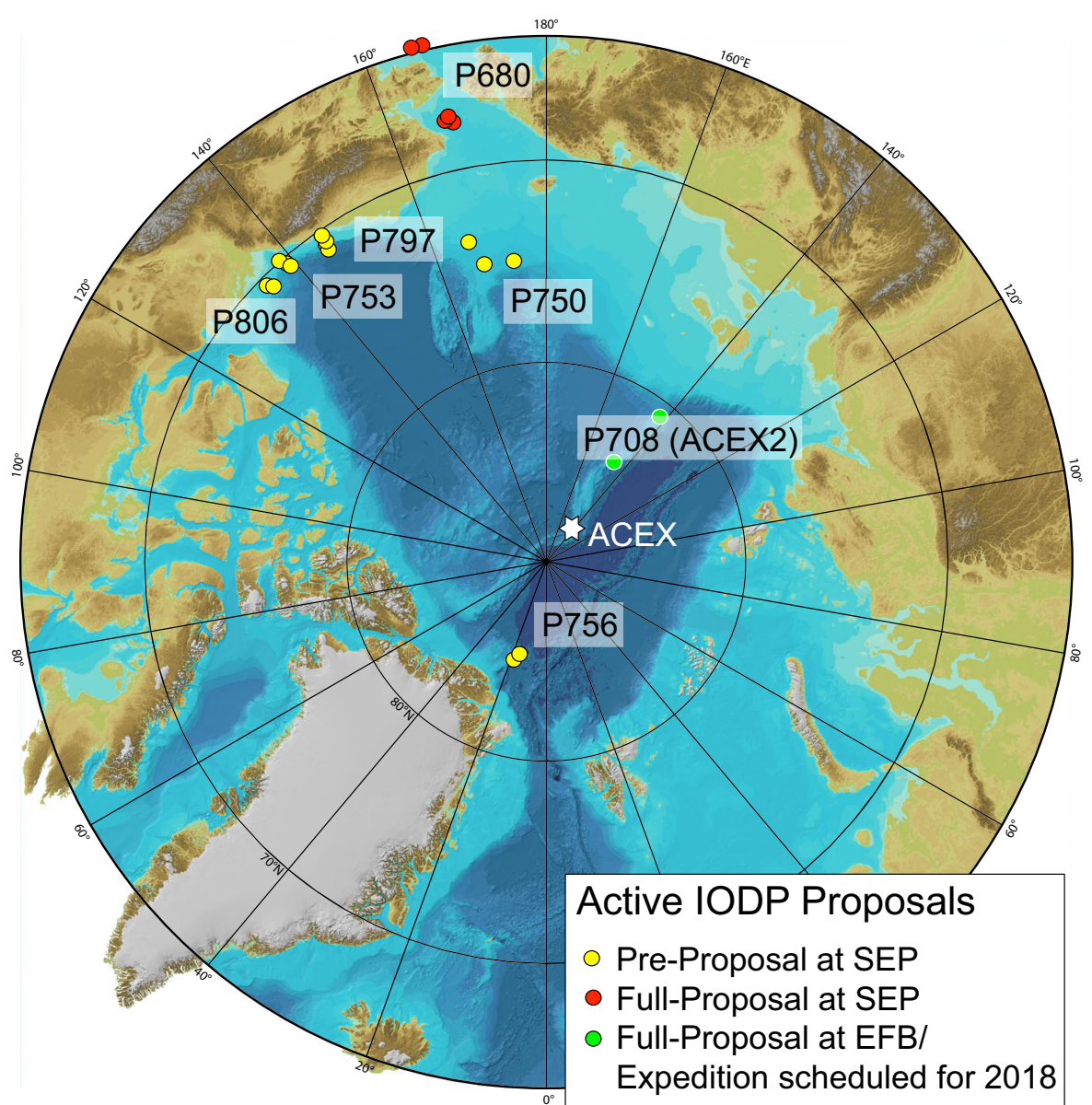

IBCAO (Jakobsson et al., 2012

Bathymetric and topographic tints (Meters above and below Mean Sea Level)

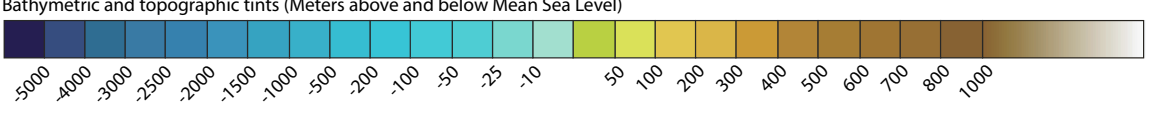

\begin{tabular}{|lll|}
\hline Proposal & Main Themelarea & Lead PI \\
& & \\
680-Full & Bering Strait Climate Change & S.J. Fowell (USA) \\
708-Full & Central Arctic Paleoceanography & R. Stein (Germany) \\
750-Pre & Bering Sea Sea Level & J. Brigham-Grette (USA) \\
753-Pre & Beaufort Sea Paleoceanography & M. O'Regan (Sweden) \\
756-Pre & Arctic Ocean Exit Gateway & M. Jakobsson (Sweden) \\
797-Pre & Alaska Beaufort Margin & C. Ruppel (USA) \\
806-Pre & Beaufort Gas Hydrate & C. Paull (USA)
\end{tabular}

poorly ventilated bottom waters and variable primary production [16, 88, 124, 128]. One prerequisite of this extreme paleoenvironmental situation was the paleogeographic boundary setting, i.e., the early Arctic Ocean was isolated from the world ocean in terms of deep-water connections (Fig. 5; [13, 54, 89, 112]). Furthermore, the huge freshwater discharge has favored the development of widespread salinity stratification resulting in a poor ventilation of the subsurface, deeper water masses and causing the high OC preservation rate. A low surface water salinity (brackish) environment during middle Eocene times is also suggested from the rare and sporadic occurrence of radiolarians [13]. Runoff-related low salinity might be indicated as well by the abundance of terrestrial palynomorphs and green algae such as Tasmanites and Botryococcus [13].

The question how and when the transition from poorly oxygenated to ventilated conditions in the Arctic Ocean did occur, is still under discussion. Subunits 1/4-1/1 (middle Miocene to recent), characterized by very low OC values of $<0.5 \%$ (Fig. 5), already represent paleoenvironmental conditions similar to the modern ones, i.e., fully ventilated water masses preventing preservation of high amount of 
labile algae-type OC. Thus, the transition from euxinic to oxic conditions in the central Arctic Ocean should have occurred within/around "Zebra" Subunit 1/5 (Fig. 5).

Based on a paleogeographic and paleobathymetric reconstruction of the Arctic Ocean, together with a physical oceanographic modelling of the evolving strait and sill conditions in the Fram Strait, Jakobsson et al. [54] suggest that across Subunit 1/5 the Arctic Ocean went from an oxygen-poor "lake stage," to a transitional "estuarine sea" phase with variable ventilation, and finally to the fully ventilated "ocean" phase.

The key question when this change from euxinic to well-oxygenated open marine conditions in the Arctic occurred cannot be answered at present. As proposed by Jakobsson et al. [54], this change was correlated with the tectonically controlled widening of the Fram Strait in the late early Miocene $(\sim 17.5 \mathrm{Ma})$ if using the age model of Backman et al. [8]. A comparison of the deep-water agglutinated foraminifera assemblages from the Lomonosov Ridge with Miocene assemblages from ODP Hole 909C in the Fram Strait, Norwegian-Greenland Sea [67], suggests that the faunal exchange between the Arctic and the Norwegian Sea and by inference the inflow of Atlantic Intermediate Water into the Arctic probably began earlier, i.e., at least since the Early Miocene [68]. The recent Os-Re isotope dates from the cross-banded and underlying Eocene age biosiliceous-rich sediments of the ACEX sequence suggest that the transition from euxinic to well-oxygenated conditions may have occurred much earlier, i.e., already in the late Eocene (Figs. 5, $6 ;[100,101])$.

\section{Need for future scientific drilling in the Arctic Ocean: "from ACEX to ACEX2"}

While the Arctic paleoceanographic and paleoclimate results from ACEX were unprecedented, major questions related to the climate history development of the Arctic Ocean from Greenhouse to Icehouse conditions during early Cenozoic times remain unanswered, largely due to the major mid-Cenozoic hiatus and partly to the poor recovery of the ACEX record (Fig. 2). In addition to elevated atmospheric $\mathrm{CO} 2$ concentrations in the early Cenozoic, other boundary conditions such as the freshwater budget, exchange between the Arctic and Pacific/ Atlantic oceans as well as the advance and retreat of major circum-Arctic ice sheets have changed dramatically during the late Cenozoic. An understanding of how these boundary conditions have influenced the form, intensity and permanence of the Arctic sea ice cover can help improve our understanding of the complex modern ocean-atmosphere-ice system and how it has evolved with global climate [93].

Following up ACEX and its cutting-edge science, several workshops for future Arctic scientific drilling have been carried out (Table 2), and further key areas and key research themes have been identified, resulting in several proposals submitted to IODP (Fig. 9; [22, 126]; http:// www.iodp.org/active-proposals). One of these proposals is related to a second scientific drilling on the Lomonosov Ridge with a focus on the reconstruction of the continuous and complete Cenozoic climate history of the Arctic Ocean. A pre-proposal outlining the main objectives was submitted in 2006, followed by a full proposal in 2013 (Proposal Full-708/“ACEX2”; [130]; http://www.iodp.org/ expeditions). The Proposal Full-708 (with the Proponent Response Letter/2014 and the Addendum/2015) is mainly based on new site survey data recovered during the $\mathrm{Po}$ larstern expeditions 2008 and 2014 [61, 123] and went through the IODP review system between 2013 and 2015 (Table 3). Finally, ACEX2 has been scheduled for drilling in 2018 .

The primary objectives of ACEX2 share several of those in the original 533-Full3 (ACEX; [7] proposal and also build on what we learned from ACEX. Some of the key scientific themes and questions extracted from the Proposal Full-708 [130] are summarized as follows:

1. History of Arctic ice sheets, sea ice, and global climate Did the Arctic Ocean climate follow the global trend shown in Fig. 2? Are the Early Eocene Climate Optimum (poorly recovered in the ACEX record) and the Oligocene and middle Miocene warmings also reflected in Arctic Ocean records? Did extensive glaciations (such as the Oi-1 and Mi-1 glaciations) develop synchronously in both the Northern and Southern Hemispheres? (Fig. 2; [155, 156]). Did major East Siberian ice sheets occur during late Pliocene-Pleistocene as recently proposed by Niessen et al. [91]? What are the related scale and timing of short- and long-term sea level changes? What is the past variability of Cenozoic sea ice in terms of frequency, extent and magnitude, a pressing scientific question - even after the accomplishment of the first ACEX campaign.

2. History of Arctic bottom and surface water circulation Black biosiliceous silty clays and clayey silts rich in organic carbon were found throughout the upper lower to middle Eocene section of the ACEX record (Figs. 5, 7), indicating poorly ventilated bottom waters and high but variable primary production [54, 128]. When and how did the change to oxygenated bottom waters typical for the Neogene and Quaternary Arctic Ocean occur? Was it in the early-middle Miocene as 

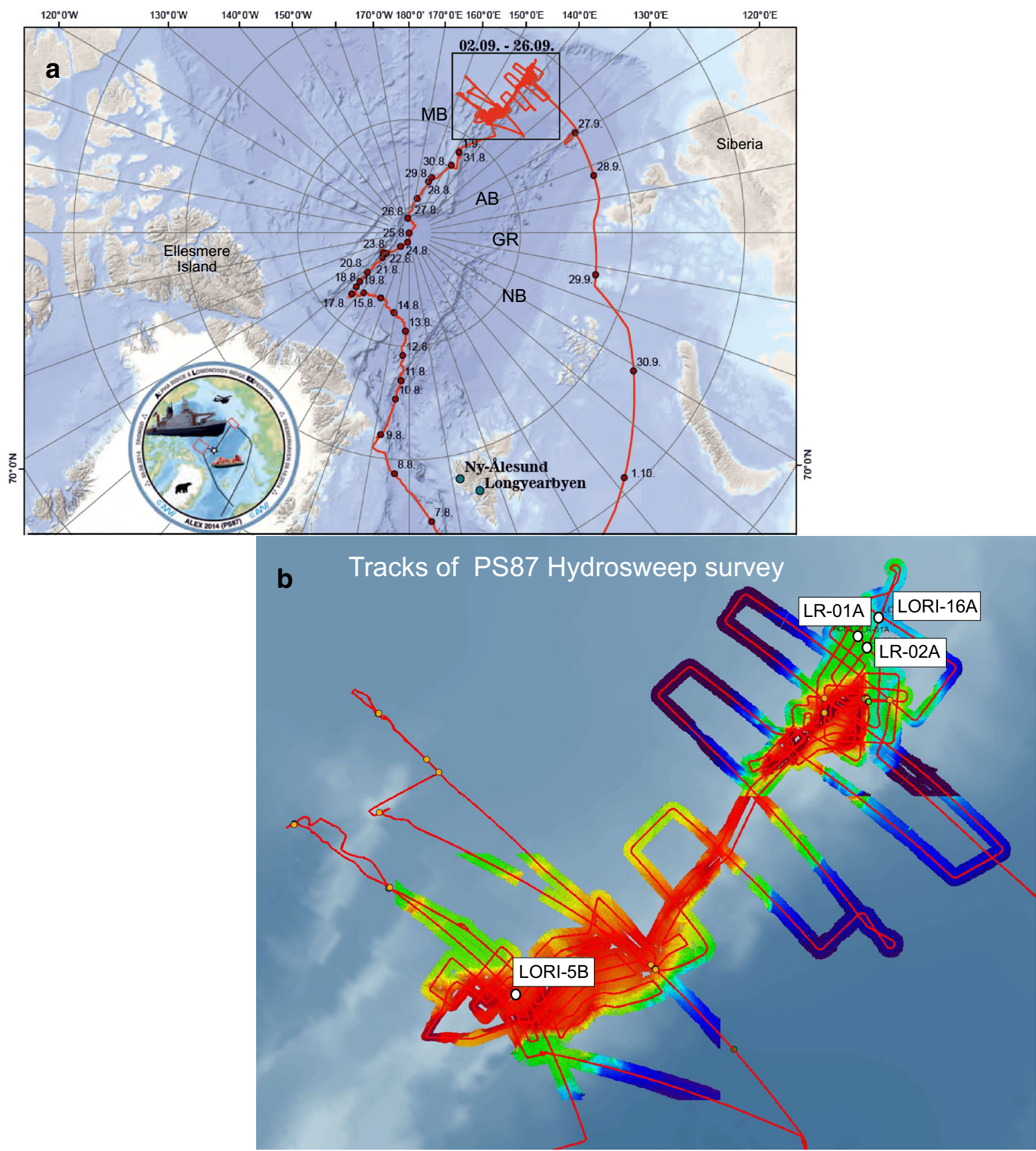

Fig. 10 a Cruise track of Polarstern Expedition PS87 from Aug 07 to Oct 01, 2014 [123]. GR Gakkel Ridge, $M B$ Makarov Basin, $A B$ Amundsen Basin, $N B$ Nansen Basin. Box (Sep 02-26) indicates main PS87 working area with track lines of multibeam bathymetric survey

proposed by Jakobsson et al. [54] and Kaminski et al. [68] or the late Eocene as proposed by Poirier and Hillaire-Marcel [101]?

3. History of Arctic river discharge

The more proximal location relative to the Siberian margin of the proposed sites in ACEX2 allows a shown in (b). b Track lines of PS 87 multibeam bathymetric and Parasound echosounding survey [123]. LR-01A, LR-02A, LORI-5B, and LORI-16A indicate locations of proposed IODP drill sites (IODP Proposal 708-Full; http://www.iodp.org/expeditions)

detailed study of the history of Arctic river discharge and its paleoenvironmental significance. In this context, the Miocene uplift of the Himalayan-Tibetan region is of particular interest as it may have triggered enhanced discharge rates of Siberian rivers and changed the freshwater balance of the Arctic's surface 


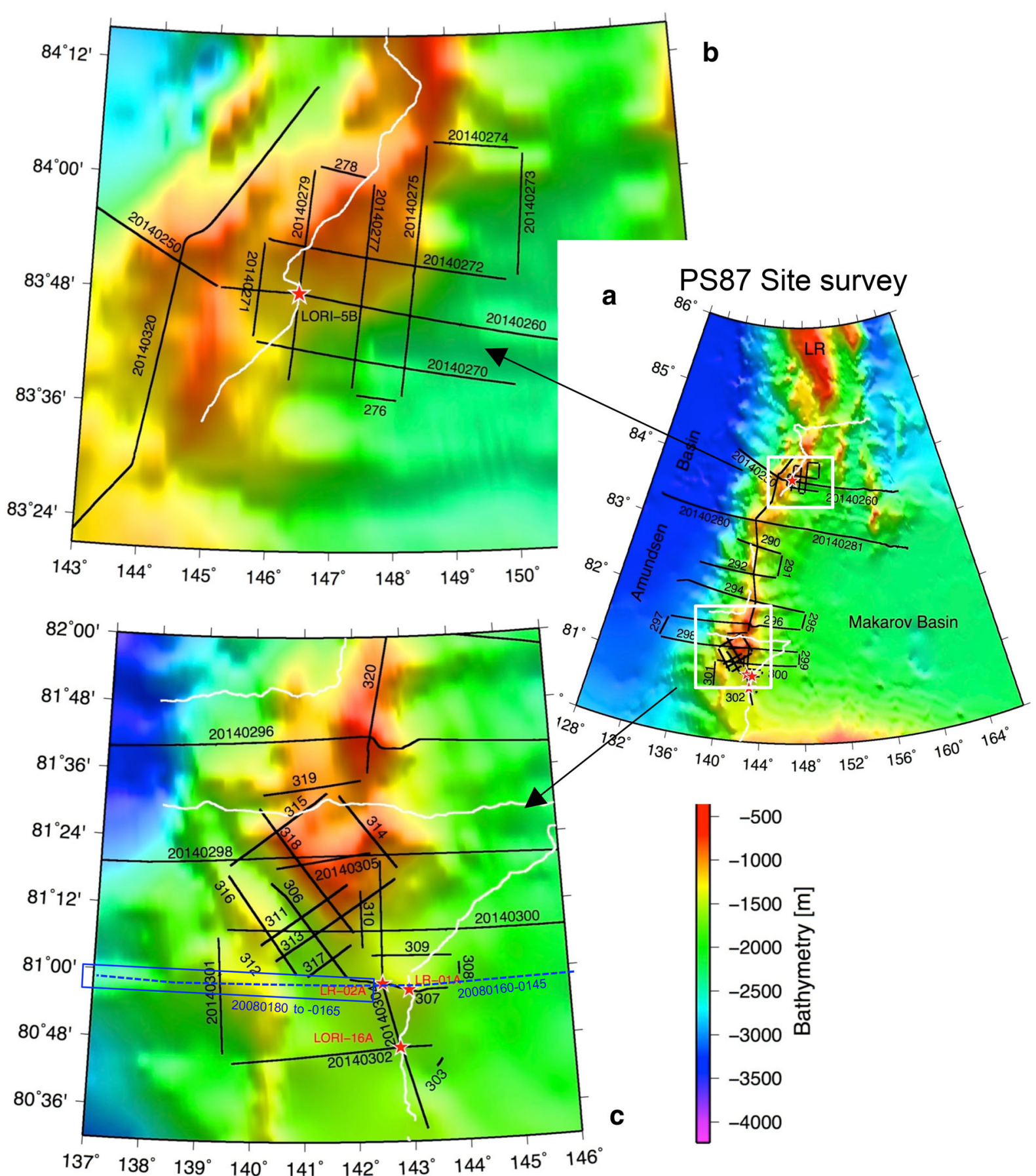

Fig. 11 a Overview map of main study of Polarstern Cruise PS87 in the Siberian part of the Lomonosov Ridge (cf. also Fig. 4). The black lines indicate the seismic reflection data gathered during the PS87 expedition. Numbers represent profile names. The line numbers are shortened in the very south to the last three digits. White lines: Seismic profiles acquired in 1998; red stars: proposed IODP drill sites, LR-Lomonosov Ridge. b Detailed survey in the area of a proposed alternate IODP drilling site LORI-5B. White line: seismic data gathered in 1998; black lines: seismic data gathered during this cruise. c Seismic profiles on the southernmost Siberian part of the Lomonosov Ridge, gathered to provide additional information around the primary drilling site LR-01A and the alternate sites LR-02A and LORI-16A. White lines: seismic data gathered in 1998; black lines: seismic data gathered during this cruise; stippled blue line: seismic lines AWI-20080145 to 20080180 [61]; red stars: proposed IODP drilling sites. (Fig. 10a-c from Jokat et al. in [123]) 
Table 5 Summary of ACEX2 site characteristics (based on multichannel seismic data)

\begin{tabular}{llll}
\hline Site & LR-01A & LR-02A & LORI-5B \\
\hline Latitude & $80.95^{\circ} \mathrm{N}$ & $80.97^{\circ} \mathrm{N}$ & $83.80^{\circ} \mathrm{N}$ \\
Longitude & $142.97^{\circ} \mathrm{E}$ & $142.47^{\circ} \mathrm{E}$ & $146.475^{\circ} \mathrm{E}$ \\
Water depth & $1405 \mathrm{~m}$ & $1458 \mathrm{~m}$ & $1334 \mathrm{~m}$ \\
Thickness Pliocene-Pleistocene & $170 \mathrm{~m}(3.2 \mathrm{~cm} / \mathrm{ky})$ & $195 \mathrm{~m}(3.7 \mathrm{~cm} / \mathrm{ky})$ & $303 \mathrm{~m}(5,7 \mathrm{~cm} / \mathrm{ky})$ \\
Top Miocene (yellow) & $165-175(170) \mathrm{mbsf}$ & $170-220(195) \mathrm{mbsf}$ & $275-330(303) \mathrm{mbsf}$ \\
Thickness Miocene & $643 \mathrm{~m}(3.6 \mathrm{~cm} / \mathrm{ky})$ & $705 \mathrm{~m}(4.0 \mathrm{~cm} / \mathrm{ky})$ & $345 \mathrm{~m}(2.0 \mathrm{~cm} / \mathrm{ky})$ \\
Top Oligocene (pink) & $790-835(813) \mathrm{mbsf}$ & $880-920(900) \mathrm{mbsf}$ & $635-660(648) \mathrm{mbsf}$ \\
Thickness Eocene-Oligocene & $312 \mathrm{~m}(1.0-1.3 \mathrm{~cm} / \mathrm{ky})$ & $300 \mathrm{~m}(0.9-1.2 \mathrm{~cm} / \mathrm{ky})$ & $477 \mathrm{~m}(1.4-1.9 \mathrm{~cm} / \mathrm{ky})$ \\
Lower Eocene (orange) & $1105-1145(1125) \mathrm{mbsf}$ & $1180-1220(1200) \mathrm{mbsf}$ & $1100-1150(1125) \mathrm{mbsf}$ \\
Basement (purple) & $1668-1681(1675) \mathrm{mbsf} *$ & $1730-1820(1775) \mathrm{mbsf}$ & $? ?$ \\
Penetration total & $1225 \mathrm{~m}$ & $1300 \mathrm{~m}$ & $1300 \mathrm{~m}$ \\
\hline
\end{tabular}

?? The basement reflector (purple) and its depth cannot be identified for the location of Site LORI-5B

* At site LR-01A, an alternate interpretation of the seismic line is possible for the basement/purple reflector, resulting in a depth of 1777-1885 (1831) mbsf

\# In brackets mean sedimentation rates are added

waters, considered to be an important factor for the formation of Arctic sea ice and onset of major glaciations [32], a hypothesis to be tested by ACEX2.

4. High-resolution characterization of the Pliocene warm period in the Arctic

During the Pliocene warm period, sea surface temperature (SST) in several ocean basins was substantially warmer $[48,78,82]$ and global mean surface temperature was estimated to be at least $\sim 3{ }^{\circ} \mathrm{C}$ higher than today [47]. How did the Arctic Ocean evolve during the Pliocene warm period and subsequent cooling? How do the marine climate records correlate with terrestrial records obtained from the Siberian Lake Elgygytgyn [17]?

5. The "hiatus problem"

What is the cause of the major hiatus spanning the late Eocene to early Miocene time interval in the ACEX record (based on the original age model of [8]? Does this hiatus in fact exist, or is it rather an interval of extremely reduced sedimentation rate as proposed by Poirier and Hillaire-Marcel ([100, 101]; Fig. 6)? If there is a major hiatus, is it related to the subsidence history of Lomonosov Ridge [94]? Was the hiatus a response to increased bottom water currents during the opening of surface and deepwater connections via the Fram Strait [87]? Additional long sedimentary records from the Arctic Ocean with good microfossil recovery are needed to solve these obvious problems in chronology and related paleoenvironmental and tectonic reconstructions.
Based on the Polarstern site survey in 2008 [61], primary and alternate ACEX2 sites were proposed [130]. The main factor for the site selection based on seismic data was the mapping of continuous and laterally conformable reflectors indicating continuous sedimentary sequences. Locations with any indications of faults, slumps, or hiatuses were avoided to ensure flat-lying, unfaulted, undeformed, and well-stratified deposits. Furthermore, locations were selected indicating appropriate thicknesses and depths feasible for drilling into and through the Cenozoic strata of interest. Depth velocity information for estimating the thickness of the sedimentary units was derived from sonobuoys [62].

During the PS87 Polarstern Cruise, a new comprehensive site survey, including multibeam-bathymetry, Parasound and seismic profiling as well as sediment coring, was carried out in the area of the proposed four drill sites, i.e., the primary Site LR-01A and the alternate sites LR-02A, LORI-16A and LORI-5B [123]. Detailed bathymetric and high-resolution Parasound profiling (Fig. 10) and highquality multichannel seismic profiles with crossing lines (Fig. 11) are available from all these four sites. Based on these data, the locations of all the originally proposed sites were approved and further alternate sites selected. During the Oden 2014 Expedition ("SWERUS"; [45]), additional multibeam-bathymetry and high-resolution Chirp data have been obtained for the alternate sites LR-02A, LORI-16A and LORI-5B. These Oden data perfectly support the PS87 Polarstern bathymetry and Parasound records.

Based on the PS87 data, seismic units were clearly identified by their reflection pattern and configuration on the new seismic lines. These data were recorded with a 

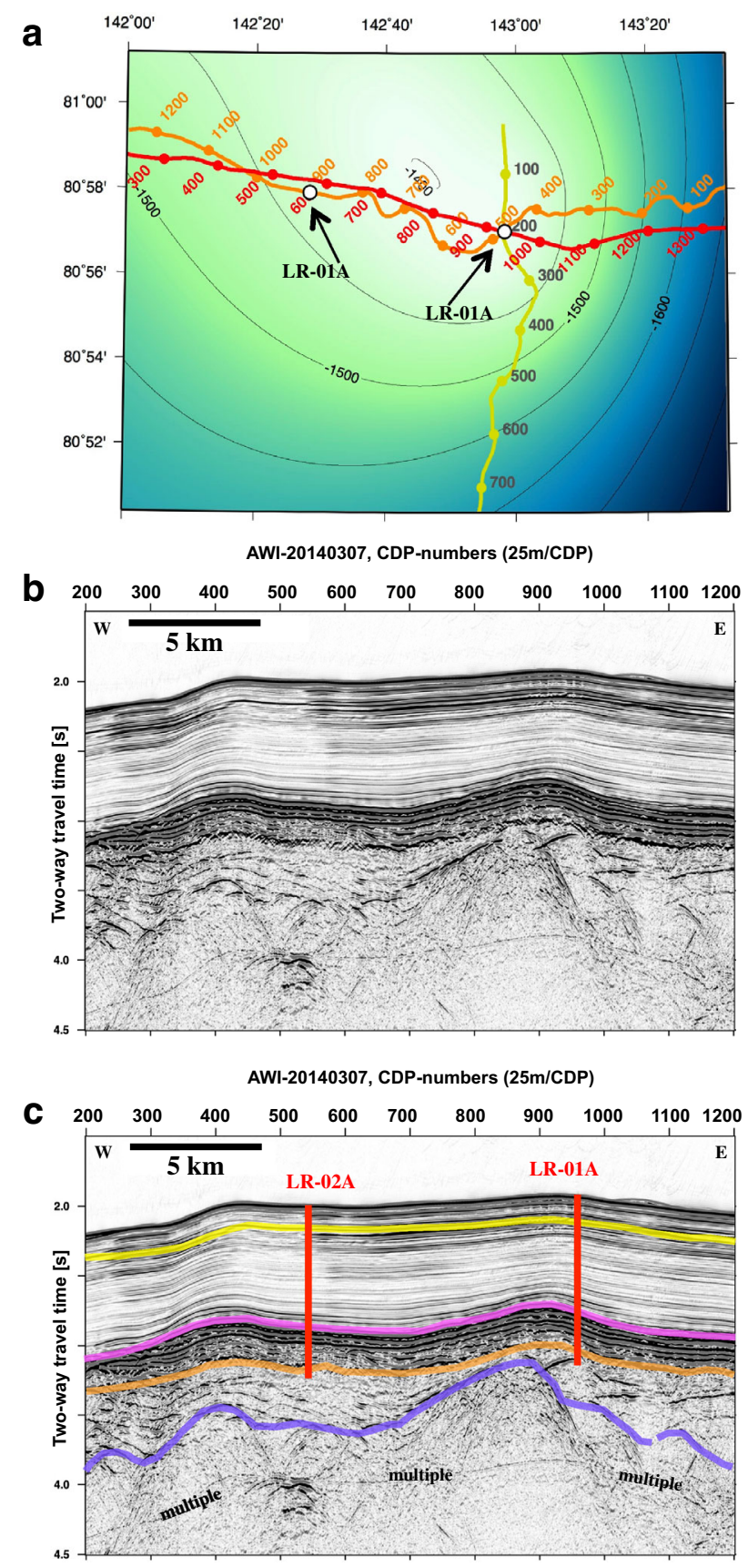

Fig. 12 a Map of the southern Lomonosov Ridge/Siberian continental margin area with location of seismic lines AWI-98597 (yellow), AWI-20080160 (orange), AWI-20140304 (dark red) and AWI20140307 (red) annotated using CDP numbers (cf., Fig. 11). b Seismic profile of line AWI-20140307 between CDP 200 and 1200. c Seismic profile of line AWI-20140307 with interpretation of reflectors. Top of Miocene (yellow reflector), top of Oligocene (pink reflector) corresponding to top of the HARS (high-amplitude reflector sequence), and lower Eocene (orange reflector) (cf., Table 5). Location and stratigraphic range of drill sites LR-01A and LR-02A are shown

3000-m-long streamer, which enabled a detailed velocity analysis and that permitted a more accurate calculation of the depths of marker horizons and the thicknesses of these units (Table 5). The age control for the sedimentary units was estimated via links of seismic lines to drill site data of the Chukchi Shelf, ACEX drilling on central Lomonosov Ridge, and onshore geology from the New Siberian Islands $[49,148]$.

At the locations of southern sites LR-01A and LR-02A, the depths of the yellow (Top Miocene), pink (Top Oligocene), and orange reflectors (Lower Eocene) are at 170, 813 , and $1125 \mathrm{~m}$, and 195,900 , and $1200 \mathrm{~m}$, respectively (Fig. 12; Table 5). That means, the Pleistocene-Pliocene, Miocene, and Oligogene-Eocene sections to be recovered at these two sites may reach thicknesses of 170 and $195 \mathrm{~m}$, 643 and $705 \mathrm{~m}$, and 312 and $300 \mathrm{~m}$, respectively. At the more northern (more ice-covered) location of Site LORI$5 \mathrm{~B}$, the top of the Oligocene can be reached in even shallower depths of about $650 \mathrm{~m}$ (Fig. 13; Table 5). Furthermore, the Parasound profiles indicate totally undisturbed, continuous sedimentation in the upper part of the sedimentary sequences at all four site locations (Fig. 14). These carefully selected sites provide the chance to get a continuous Cenozoic sedimentary section that will allow to study the long-term climate change from Greenhouse to Icehouse conditions but also give the chance to study the Neogene-Pleistocene climate history in a higher time resolution than it was possible with ACEX sediments.

As the drill sites are located in the ice-covered Arctic Ocean, a mission-specific platform (MSP) is needed for the drilling operation. In comparison with the work area of the ACEX Expedition in 2004, however, ice conditions of ACEX2 are significantly less severe, especially when looking at the sea ice cover in recent years. In 2007 and 2012, the area of some of the proposed drilling operations was even completely ice-free or close to the ice edge during September (Fig. 1). Nevertheless, ice management operations by means of additional icebreaker support are needed to guarantee safe and successful drilling operations.

The ACEX2 MSP-type drilling campaign has been scheduled by the ECORD Facility Board for late summer/ early autumn 2018, and detailed planning activities including selection of drilling platform, ice management etc. by the ECORD Science Operator and the 708 proponents have begun. As general drilling strategy, we propose one primary drill site on southern Lomonosov Ridge, Site LR-01A or in its neighborhood (Fig. 11c). At this site, we propose drilling three $\mathrm{APC} / \mathrm{XCB} / \mathrm{RCB}$ holes down to about $1300 \mathrm{~m}$ (Table 5). This is required to ensure recovery of a complete composite stratigraphic sediment record and to meet our highest priority paleoceanographic objective, the continuous long-term Cenozoic climate history of the central Arctic Ocean. Based on its protected location and the existing seismic profiles, a continuous record without a major hiatus is very probable. Logging should be carried out at one of the holes. 

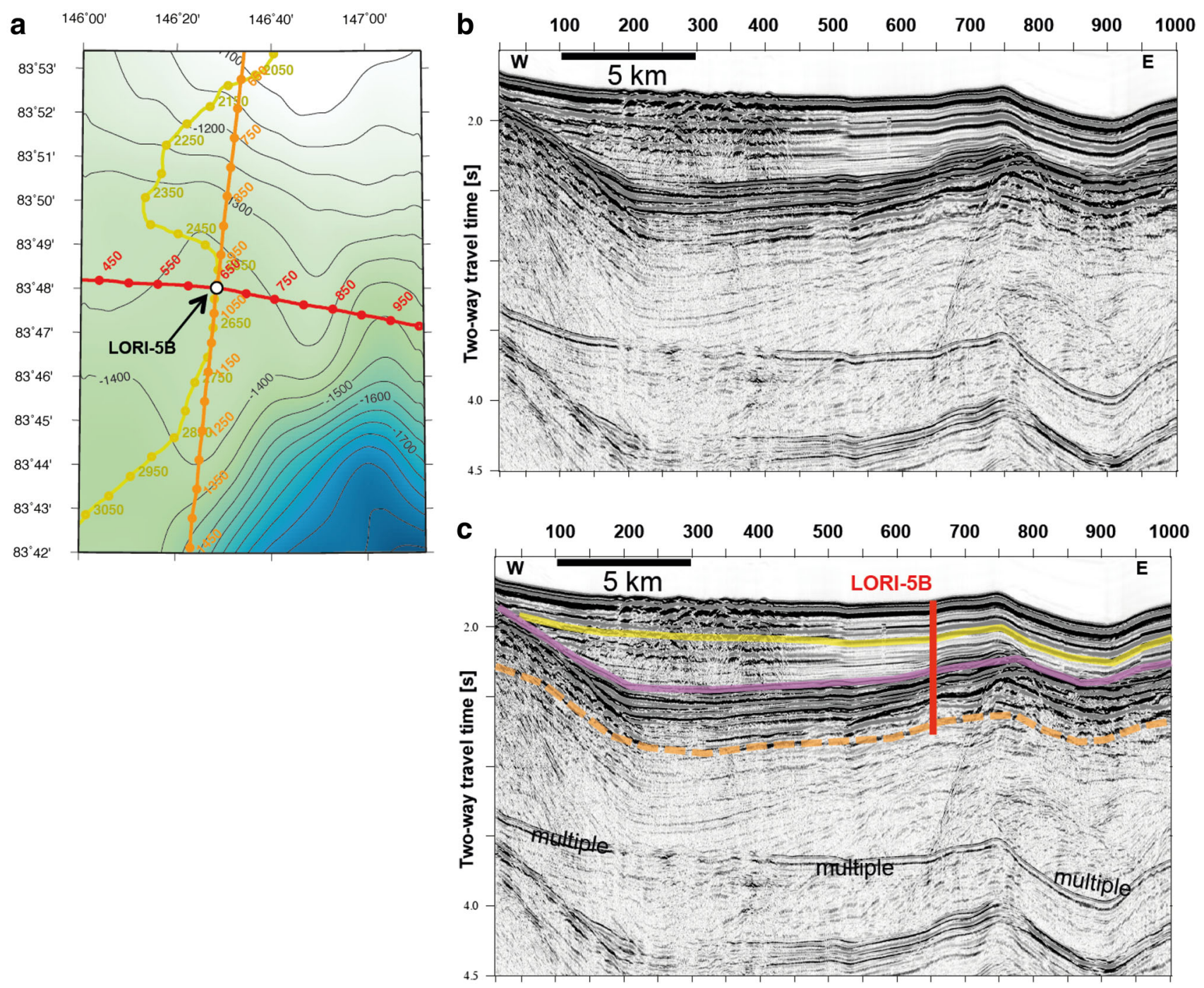

Fig. 13 a Detailed map of the area around Site LORI-5B with location of seismic lines AWI-98565 (yellow), AWI-20140260 (red), and AWI-20140279 (orange) annotated using CDP numbers (cf., Fig. 11). b Seismic profile of line AWI-20140260 between CDP 0 and 1000. c Seismic profile of line AWI-20140260 with interpretation of

Finally, it must be emphasized that all questions dealing with the Arctic Ocean paleoclimatic (and tectonic) history cannot be answered by one additional expedition. Additional future drilling campaigns will be needed, some of which hopefully can be carried out within the current phase of IODP (Fig. 9; [125, 126]).

\section{Conclusions}

As the first scientific drilling in the permanently ice-covered central Arctic Ocean, IODP Expedition 302-the Arctic Coring Expedition (ACEX)—was certainly a benchmark in Arctic geoscientific research. By studying reflectors. Top of Miocene (yellow reflector), top of Oligocene (pink reflector) corresponding to top of the HARS (high-amplitude reflector sequence), and lower Eocene (orange reflector) (cf., Table 5). Location and stratigraphic range of drill site LORI-05B are shown

the unique about 400-m-thick ACEX sequence of Upper Cretaceous to Quaternary sediments recovered on Lomonosov Ridge close to the North Pole, a large number of scientific discoveries that describe previously unknown Arctic paleoenvironments, have been obtained during the last decade.

While highly successful, the ACEX record also has three important limitations:

1. Based on the different age models, the ACEX sequence either contains a large hiatus spanning the time interval from the late Eocene to the middle Miocene or a long-lasting time interval of strongly condensed sedimentation rates. In any case, this critical time interval, i.e., when prominent changes in 
a

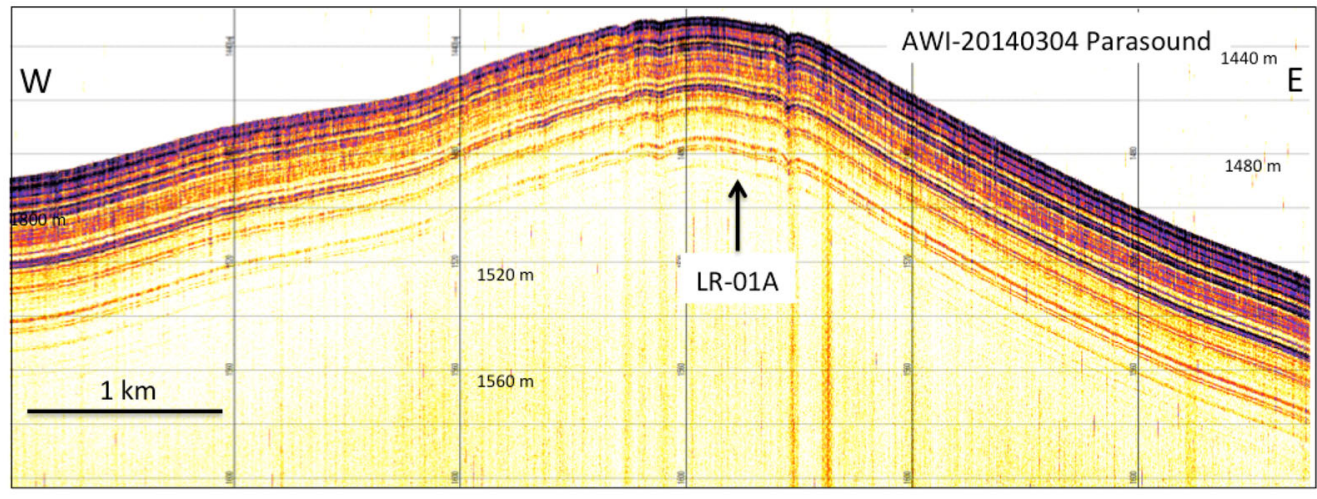

b

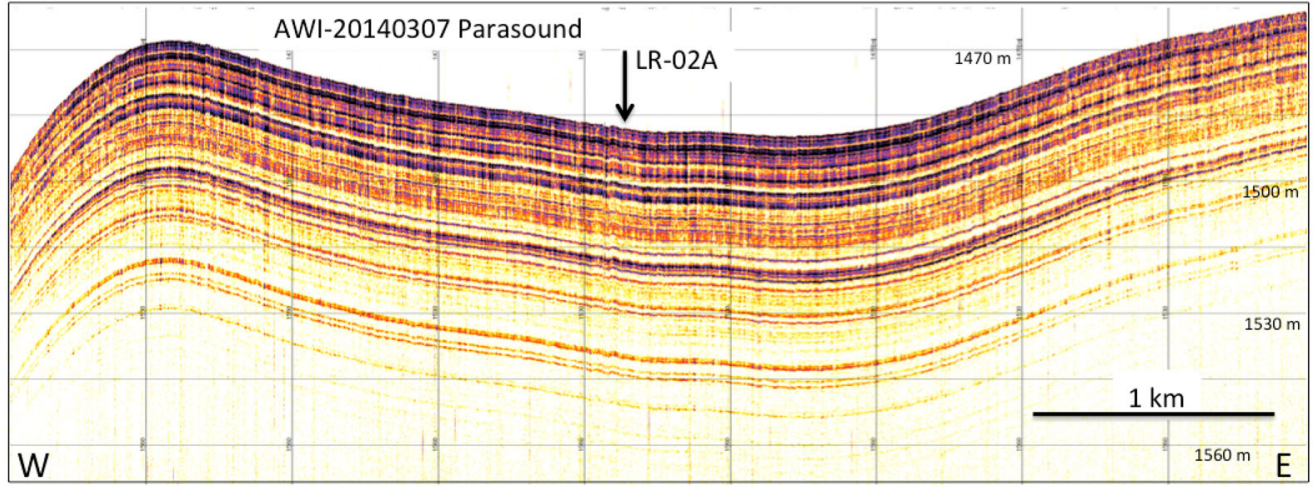

c
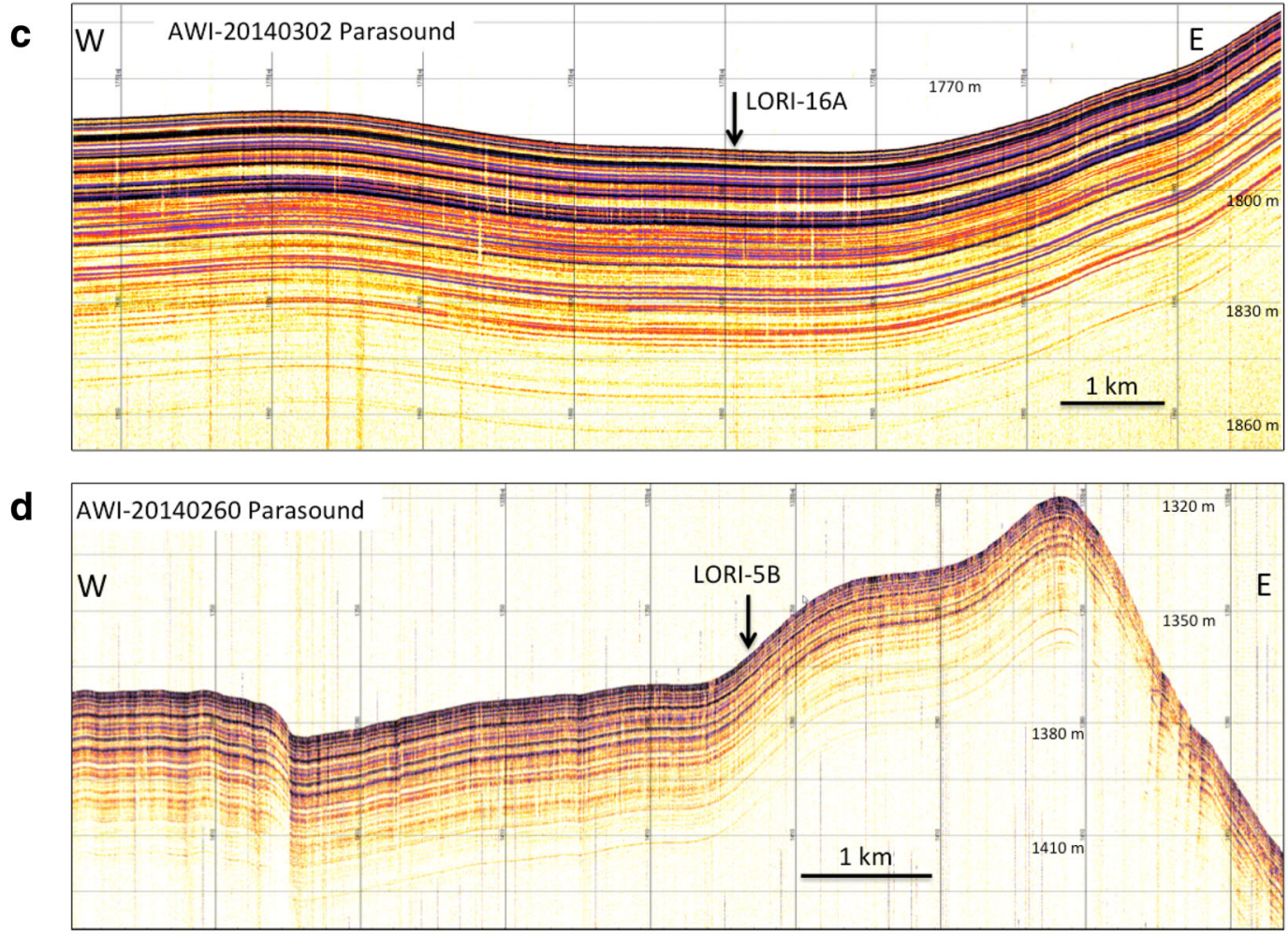

Fig. 14 Sediment echosounding (Parasound) profiles across locations of proposed drill sites a LR-01A, b LR-02A, c LORI-16A, and d LORI05B 
global climate took place during the transition from the early Cenozoic Greenhouse world to the late Cenozoic Icehouse world, is not at all or not well represented in the ACEX sequence.

2. The generally poor recovery as well as the partly poor preservation of microfossils prevented detailed and continuous reconstruction of Cenozoic climate history.

3. The second overall paleoceanographic objective of the original ACEX program, the high-resolution reconstruction of Arctic rapid climate change during Neogene to Pleistocene times, could not be accomplished because drilling on the southern Lomonosov Ridge was not carried out due to limitations with respect to operational constraints.

Having this in mind, we proposed a return to the Lomonosov Ridge for a second MSP drilling campaign within the framework of IODP (ACEX2) to fill these major gaps in our knowledge on Arctic Ocean paleoenvironmental history through Cenozoic times and its relationship to the global climate history. Based on the experience of ACEX and the comprehensive site survey expeditions in 2008 and 2014, we are convinced that our ACEX2 key goal, i.e., getting a complete record of Cenozoic climate history, can be achieved by careful site selection, appropriate drilling technology, and applying multiproxy approaches to paleoceanographic, paleoclimatic, and age model reconstructions. ACEX2 is scheduled for late summer/early autumn 2018, and a detailed planning by the ECORD Science Operator and the ACEX2 proponents is in progress.

Acknowledgements We gratefully thank the PS87 Science Party as well as Captain Schwarze and his crew of RV Polarstern for the excellent support and cooperation during the entire cruise. Many thanks also to our ACEX2 co-proponents and the IODP review boards and facilities. Last but not least we thank the three anonymous reviewers for numerous constructive suggestions for improving the manuscript. This publication is a contribution to the Research Programme PACES, Topic 3 (Lessons from the Past) of the Alfred Wegener Institute Helmholtz Centre for Polar und Marine Research (AWI).

\section{References}

1. Aagaard K, Barrie LA, Carmack EC (1996) US and Canadian researchers explore Arctic Ocean. EOS Trans Am Geophys Un 77(22):209-210

2. Aagaard K, Carmack EC (1989) The role of sea ice and other fresh water in the Arctic circulation. J Geophys Res 94(C10): 14485-14498

3. ACIA (2004) Impacts of a warming Arctic: Arctic climate impact assessment. Cambridge University Press, Cambridge, p 139. (http://www.acia.uaf.edu)

4. ACIA (2005) Arctic climate impact assessment. Cambridge University Press, Cambridge, p 1042
5. Anderson LG, Carlsson ML (eds.) (1991) International Arctic Ocean expedition 1991, Icebreaker ODEN-Cruise report. Swedish Polar Research Secretariat, p 128

6. Arora A, Singh PK (2003) Comparison of biomass productivity and nitrogen fixing potential of Azolla SPP. Biomass Bioenergy 24:175-178

7. Backman J, Bogdanov N, Coakley B, Edwards M, Forsberg R, Jackson R, Jakobsson M, Jokat W, Kristoffersen Y, Mayer L, Moran K (2002) Paleoceanographic and tectonic evolution of the central Arctic Ocean. ODP/IODP Proposal 533-Full3. http:// www.eso.ecord.org/docs/533.pdf

8. Backman J, Jakobsson M, Frank M, Sangiorgi F, Brinkhuis H, Stickley C, O’Regan M, Løvlie R, Pälike H, Spofforth D, Gattacecca J, Moran K, King J, Heil C (2008) Age model and coreseismic integration for the Cenozoic Arctic Coring expedition sediments from the Lomonosov Ridge. Paleoceanography 23, PA1S03

9. Backman J, Jacobson M, Knies J, Knudsen J, Kristoffersen Y, Lif A, Musatov E, Stein R (1997) Geological coring and high resolution chirp sonar profiling. Cruise report, Polarforskningssekretaariatets arsbok 1995/96, Stockholm, 64-66

10. Backman J, Jakobsson M, Løvlie R, Polyak L, Febo LA (2004) Is the central Arctic Ocean a sediment starved basin? Quat Sci Rev 23:1435-1454

11. Backman J, Moran K (2008) Introduction to special section on Cenozoic Paleoceanography of the Central Arctic Ocean. Paleoceanography 23, PA1S01. doi:10.1029/2007PA001516

12. Backman J, Moran K (2009) Expanding the Cenozoic paleoceanographic record in the central Arctic Ocean: IODP expedition 302 synthesis. Cent Eur J Geosci 1:157-175

13. Backman J, Moran K, McInroy DB et al (2006) In: Proceedings IODP, 302, College Station, Texas (Integrated Ocean Drilling Program Management International, Inc.). doi:10.2204/iodp. proc.302.104.2006

14. Barke J, van der Burgh J, van Konijnenburg-van Cittert JHA, Collinson ME, Pearce MA, Bujak J, Heilmann-Clausen C, Speelman EN, van Kempen MML, Reichart G-J, Lotter AF, Brinkhuis H (2012) Coeval Eocene blooms of the freshwater fern Azolla in and around Arctic and Nordic seas. Palaeogeogr Palaeoclimatol Palaeoecol 337-328:108-119

15. Boström K, Thiede J (1984) YMER-80, Swedish Arctic Expedition-Cruise report for marine geology and geophysics, sediment core descriptions. Medd Stockh Univ Geol Inst 260:123

16. Boucsein B, Stein R (2008) Black shale formation in the late Paleocene/early Eocene Arctic Ocean and paleoenvironmental conditions: new results from a detailed organic petrological study. Mar Pet Geol 26(3):416-426

17. Brigham-Grette J, Melles M, Minyuk P, Andreev A et al (2013) Pliocene warmth, extreme polar amplification, and stepped pleistocene cooling recorded in NE Russia. Science 340:1421-1427

18. Brinkhuis H, Schouten S, Collinson ME, Sluijs A, Damsté JSS, Dickens GR, Huber M, Cronin TM, Onodera J, Takahashi K, Bujak JP, Stein R, van der Burgh J, Eldrett JS, Harding IC, Lotter AF, Sangiorgi F, Cittert HK, de Leeuw JW, Matthiessen J, Backman J, Moran K, The Expedition 302 Scientists (2006) Episodic fresh surface waters in the Eocene Arctic Ocean. Nature 441:606-609

19. Bujak JP, Brinkhuis H (1998) In: Aubry M-P, Lucas SG, Berggren WA (eds) Late paleocene-early eocene climatic and biotic events in the marine and terrestrial records. Columbia Univ. Press, New York, pp 277-295

20. Clark DL, Whitman RR, Morgan KA, Mackey SD (1980) Stratigraphy and glacial-marine sediments of the Amerasian Basin, central Arctic Ocean. Geol Soc Am Spec Pap 181:57 
21. Clark DL, Byers CW, Pratt LM (1986) Cretaceous black mud from the central Arctic Ocean. Paleoceanography 1:265-271

22. Coakley B, Stein R (2010) Arctic Ocean scientific drilling: the next frontier. Sci Drill 9:45-49

23. Cronin TM, Smith SA, Eynaud F, O'Regan M, King J (2008) Quaternary paleoceanography of the central Arctic based on Integrated Ocean Drilling Program Arctic Coring Expedition 302 foraminiferal assemblages. Paleoceanography 23, PA1S18. doi:10.1029/2007PA001484

24. Collinson ME, Barke J, van der Burgh J, Konijnenburg V, Cittert V (2009) A new species of the freshwater fern Azolla (Azollaceae) from the Eocene Arctic Ocean. Rev Palaeobot Palynol 155:1-14

25. Darby DA (2008) The Arctic perennial ice cover over the last 14 million years. Paleoceanography. doi:10.1029/2007PA001479

26. Darby DA (2014) Ephemeral formation of perennial sea ice in the Arctic Ocean during the middle Eocene. Nat Geosci. doi:10. 1038/NGEO2068

27. Darby D, Jakobsson M, Polyak L (2005) Icebreaker expedition collects key Arctic seafloor and ice data. EOS Trans 86(52):549-552

28. Davies A, Kemp AES, Pälike H (2011) Tropical ocean-atmosphere controls on inter-annual climate variability in the Cretaceous Arctic. Geophys Res Lett. doi:10.1029/2010GL046151

29. Davies A, Kemp AES, Pike J (2009) Late Cretaceous seasonal ocean variability from the Arctic. Nature 460:254-258

30. DeConto RM, Pollard D, Wilson PA, Pälike H, Lear CH, Pagani M (2008) Thresholds for Cenozoic bipolar glaciations. Nature 455:652-656

31. Dickens GR, O’Neil JR, Rea DK, Owen RM (1995) Dissociation of oceanic methane hydrate as a cause of the carbon isotope excursion at the end of the Paleocene. Paleoceanography 10:965-971

32. Driscoll NW, Haug GH (1998) A short circuit in thermohaline circulation: a cause for northern hemisphere glaciation? Science 282:436-438

33. Edwards MH, Coakley BJ (2003) SCICEX investigations of the Arctic Ocean system. Chem Erde 63:281-392

34. Eldrett JS, Harding IC, Wilson PA, Butler E, Roberts AP (2007) Continental ice in Greenland during the Eocene and Oligocene. Nature. doi:10.1038/nature05591

35. Escutia C, Brinkhuis H, Klaus A, the IODP Expedition 318 Scientists (2011) IODP expedition 318: from Greenhouse to Icehouse at the Wilkes Land Antarctic margin. Sci Drill 12:15-23. doi:10.2204/iodp.sd.12.02.2011

36. Eynaud F, Cronin TM, Smith SA, Zaragosi S, Mavel J, Mary Y, Mas V, Pujol C (2009) Morphological variability of the planktonic foraminifer Neogloboquadrina pachyderma in the late Pleistocene of the ACEX cores. Micropaleontology 55:101-116

37. Firth JV, Clark DL (1998) An early Maastrichtian organicwalled phytoplankton cyst assemblage from an organic-walled black mud in Core F1-533, Alpha Ridge: evidence for upwelling conditions in the Cretaceous Arctic Ocean. Mar Micropaleont 34:1-27

38. Frank M, Backman J, Jakobsson M, Moran K, O'Regan M, King J, Haley BA, Kubik PW, Garbe-Schönberg D (2008) Beryllium isotopes in central Arctic Ocean sediments over the past 12.3 million years: stratigraphic and paleoclimatic implications. Paleoceanography. doi:10.1029/2007PA001478

39. Friedrich O, Norris RD, Erbacher J (2012) Evolution of middle to late Cretaceous oceans-A 55 m.y. record of Earth's temperature and carbon cycle. Geology 40:107-110

40. Fronval T, Jansen E (1996) Late Neogene paleoclimates and paleoceanography in the Iceland Norweigian Sea: evidence from the Iceland and Vøring Plateaus. In: Thiede J, Myhre AM, Firth JV, Johnson GL, Ruddiman WF (eds.), Proc. ODP, Sci. Results,
151, College Station, Texas (Ocean Drilling Program), pp 455-468

41. Fütterer DK (1992) ARCTIĆ91: the Expedition ARK-VIII/3 of RV "Polarstern" in 1991. Rep Pol Res 107:267

42. Fütterer DK (1994) The Expedition ARCTIĆ93 Leg ARK IX/4 of RV "Polarstern" 1993. Rep Pol Res 149:244

43. Grantz A, Clark DL, Phillips RL, Srivastava SP (1998) Phanerozoic stratigraphy of Northwind Ridge, magnetic anomalies in the Canada Basin, and the geometry and timing of rifting in the Amerasia Basin, Arctic Ocean. Geol Soc Am Bull 110:801-820

44. Grönlund E (ed.) (2001) Swedarctic 2001. Polarforskningssekretariatets Årsbok 2001, pp 44-76

45. Gustafsson Ö, Jakobsson M (eds.) (2015) The Swedish-RussianUS Arctic Ocean investigation of climate-cryosphere-carbon interaction-The SWERUS-C3 2014 Expedition Cuise report. http://polarforskningsportalen.se/en/arktis/expedition/swerus-c3/

46. Haley BA, Frank M, Spielhagen RF, Eisenhauer A (2008) Influence of brine formation on Arctic Ocean circulation over the past 15 million years. Nat Geosci 1:68-72

47. Haywood AM, Valdes PJ (2004) Modelling Pliocene warmth: contribution of atmosphere, oceans and cryosphere. Earth Planet Sci Lett 218:363-377

48. Haywood AM, Dekens P, Ravelo AC, Williams M (2005) Warmer tropics during the mid-Pliocene? Evidence from alkenone paleothermometry and a fully coupled ocean-atmosphere GCM. Geochem Geophys Geosyst 6:Q03010

49. Hegewald A, Jokat W (2013) Tectonic and sedimentary structures in the northern Chukchi region, Arctic Ocean. J Geophys Res. doi:10.1002/jgrb.50282

50. Holmes RM, McClelland JW, Peterson BJ, Shiklomanov AI, Zhulidov AV, Gordeev VV, Bobrovitskaya N (2002) A circumpolar perspective on fluvial sediment flux to the Arctic Ocean. Glob Biogeochem Cycles 16(4):46-51. doi:10.1029/ 2002GB001920

51. Hovland M (ed) (2001) The high-Arctic drilling challenge. Final report of the arctićs role in global change program planning group (APPG), Ocean Drilling Program, p 38

52. Immonen N (2013) Surface microtextures of ice-rafted quartz grains revealing glacial ice in the Cenozoic Arctic. Palaeogeogr Palaeoclimatol Palaeoecol 374:293-302

53. Jackson HR, Mudie PJ, Blasco SM (1985) Initial geological report on CESAR - The Canadian expedition to study the Alpha Ridge Arctic Ocean. Geol Surv Can Pap 84(22):177

54. Jakobsson M, Backman J, Rudels B, Nycander J, Frank M, Mayer L, Jokat W, Sangiorgi F, O’Regan M, Brinkhuis H, King J, Moran K (2007) The early Miocene onset of a ventilated circulation regime in the Arctic Ocean. Nature 447:986-990

55. Jakobsson M (1999) First high-resolution chirp sonar profiles for the central Arctic Ocean reveal erosion of Lomonosov Ridge sediments. Mar Geol 158:111-123

56. Jakobsson M, Marcussen C, Lomrog SP (2008) Lomonosov Ridge Off Greenland 2007 (LOMROG)—Cruise report: Geol Surv Den Greenl

57. Jakobsson M, Mayer L, Coakley B, Dowdeswell Julian A, Forbes S, Fridman B, Hodnesdal H, Noormets R, Pedersen R, Rebesco M, Schenke HW, Zarayskaya Yu, Accettella D, Armstrong A, Anderson RM, Bienhoff P, Camerlenghi A, Church I, Edwards M, Gardner JV, Hall JK, Hell B, Hestvik O, Kristoffersen Y, Marcussen C, Mohammad R, Mosher D, Nghiem SV, Pedrosa MT, Travaglini PG, Weatherall P (2012) The international bathymetric chart of the Arctic Ocean (IBCAO) Version 3.0. Geophys Res Lett 39(12):12609

58. Jenkyns HC, Forster A, Schouten S, Sinninghe Damsté JS (2004) High temperatures in the late Cretaceous Arctic Ocean. Nature 432:888-892 
59. Johannessen OM, Bengtsson L, Miles MW, Kuzmina SI, Semenov VA, Alekseev GV, Nagurnyi AP, Zakharov VF, Bobylev LP, Pettersson LH, Hasselmann K, Cattle HP (2004) Arctic climate change, observed and modelled temperature and sea-ice variability. Tellus 56A(4):328-341

60. Jokat W (2005) The sedimentary structure of the Lomonosov Ridge between $88^{\circ} \mathrm{N}$ and $80^{\circ} \mathrm{N}$. Geophys J Int 163:698-726

61. Jokat W (ed.) (2009) The expedition of the research vessel "Polarstern" to the Arctic in 2008 (ARK-XXIII/3) Berichte zur Polar- und Meeresforschung (Reports on Polar and Marine Research), Bremerhaven, Alfred Wegener Institute for Polar and Marine Research, 597, p 266

62. Jokat W, Ickrath M, (2015) Structure of ridges and basins off East Siberia along $81^{\circ} \mathrm{N}$, Arctic Ocean. Marine Petroleum Geology 64:222-232. doi:10.1016/j.marpetgeo.2015.02.047

63. Jokat W, Stein R, Rachor E, Schewe I (1999) Expedition gives fresh view of central Arctic geology. EOS Trans 80(465):472-473

64. Jokat W, Uenzelmann-Neben G, Kristoffersen Y, Rasmussen TM (1992) Lomonosov Ridge: a double-sided continental margin. Geology 20:887-890

65. Jokat W, Weigelt E, Kristoffersen Y, Rasmussen TM (1995) New insights into the evolution of Lomonosov Ridge and the Eurasia Basin. Geophys J Int 122:378-392

66. Kaban'kov V, Andreeva I, Ivanov V, Petrova V (2004) The geotectonic nature of the Central Arctic Morphostructures and geological implications of bottom sediments for its interpretation. Geotectonics 6:33-48

67. Kaminski MA, Silye L, Kender S (2005) Miocene deep-water agglutinated foraminifera from ODP Hole 909C: implications fort he paleoceanography of the Fram Strait area, Greenland Sea. Micropaleontology 51:373-403

68. Kaminski MA, Silye L, Kender S (2009) Miocene deep-water agglutinated foraminifera from the Lomonosov Ridge and the opening of the Fram Strait. Micropaleontology 55:117-135

69. Kender S, Kaminski MA (2013) Arctic Ocean benthic foraminiferal faunal change associated with the onset of perennial sea ice in the middle Miocene. J Foramin Res 43:99-109

70. Kennett JP, Shackleton NJ (1976) Oxygen isotopic evidence for the development of the psychrosphere $38 \mathrm{Myr}$ ago. Nature 260:513-515

71. Kennett JP, Stott LD (1991) Abrupt deep-sea warming, palaeoceanographic changes and benthic extinctions at the end of the Palaeocene. Nature 353:225-229

72. Knies J, Mann U, Popp BN, Stein R, Brumsack H-J (2008) Surface water productivity and paleoceanographic implications in the Cenozoic Arctic Ocean. Paleoceanography 23, PA1S16, pp. 1-12. doi:10.1029/2007PA001455

73. Krause G (1969) Ein Beitrag zum Problem der Erneuerung des Tiefenwassers im Arkona-Becken. Kieler Meeresforschung 25:268-271

74. Kristoffersen Y (1990) Eurasian Basin, in the Arctic Ocean region, geology of North America, vol. L, pp 365-378, edited by Grantz A, Johnson L, Sweeny JF, Geological Society of America, Boulder

75. Kristoffersen Y, Buravtsev V, Jokat W, Poselov V (1997) Seismic reflection surveys during Arctic Ocean-96. Cruise report, Polarforskningssekretaariatets arsbok 1995/96, Stockholm, pp 75-77

76. Kristoffersen Y, Mikkelsen N (2004) Scientific drilling in the Arctic Ocean and the site survey challenge: Tectonic, paleoceanographic and climateic evolution oft he Polar Basin. Report of the JEODI Workshop, Copenhagen 2003. Geological Survey of Denmark and Greenland, Special Publication, p 85; ISBN: 87-7871-133-9

77. Krylov AA, Andreeva IA, Vogt C, Backman J, Krupskaya VV, Grikurov GE, Moran K, Shoji H (2008) A shift in heavy and clay mineral provenance indicates a middle miocene onset of a perennial Sea-Ice Cover in the Arctic Ocean. Paleoceanography 23, PA1S06. doi:10.1029/2007PA001497

78. Lawrence KT, Liu Z, Herbert TD (2006) Evolution of the eastern tropical Pacific through Plio-Pleistocene glaciation. Science 312:79-83

79. Lear CH, Elderfield PA, Wilson PA (2000) Cenozoic deep-sea temperatures and global ice volumes from $\mathrm{Mg} / \mathrm{Ca}$ in benthic foraminiferal calcite. Science 287:269-272

80. Lourens LJ, Sluijs A, Kroon D, Zachos JC, Thomas E, Röhl U, Bowles J, Raffi I (2005) Astronomical pacing of late Palaeocene to early Eocene global warming events. Nature 435:1083-1087

81. Mann U, Knies J, Chand S, Jokat W, Stein R, Zweigel J (2009) Evaluation and modelling of Tertiary source rocks in the central Arctic Ocean. Mar Petrol Geol 26(8):1624-1639. doi:10.1016/j. marpetgeo.2009.01.008

82. Marlow JR, Lange CB, Wefer G, Rosell-Melé A (2000) Upwelling intensification as part of the Pliocene-Pleistocene climate transition. Science 290:2288-2291

83. Matthiessen J, Brinkhuis H, Poulsen N, Smelror M (2009) Decahedrella martinheadii Manum 1997-a stratigraphically and paleoenvironmentally useful Miocene acritarch of the mhigh northern latitudes. Micropaleontology 55:171-186

84. Matthiessen J, Knies J, Vogt C, Stein R (2009) Pliocene paleoceanography of the Arctic Ocean and subarctic seas. Phil Trans R Soc A. doi:10.1098/rsta.2008.0203

85. Miller KG, Fairbanks RG, Mountain GS (1987) Tertiary oxygen isotope synthesis, sea level history, and continental margin erosion. Paleoceanography 2:1-19

86. Miller KG, Wright JD, Fairbanks RG (1991) Unlocking the ice house: oligocene-Miocene oxygen isotopes, eustasy, and margin erosion. J Geophys Res 96(B4):6829-6849

87. Moore TC, The Expedition 302 Scientists (2006) Sedimentation and subsidence history of the Lomonosov Ridge. In: Backman J, Moran K, McInroy DB, Mayer LA, the Expedition 302 Scientists, Proc. IODP, 302: Edinburgh (Integrated Ocean Drilling Program Management International, Inc.). doi:10.2204/iodp.proc.302.105.2006

88. Moran K, Backman J, Brinkhuis H, Clemens SC, Cronin T, Dickens GR, Eynaud F, Gattacceca J, Jakobsson M, Jordan RW, Kaminski M, King J, Koc N, Krylov A, Martinez N, Matthiessen J, McInroy D, Moore TC, Onodera J, O'Regan AM, Pälike H, Rea B, Rio D, Sakamoto T, Smith DC, Stein R, St. John K, Suto I, Suzuki N, Takahashi K, Watanabe M, Yamamoto M, Frank M, Jokat W, Kristoffersen Y (2006) The Cenozoic palaeoenvironment of the Arctic Ocean. Nature 441:601-605

89. Mutterlose J, Brumsack H, Flögel S, Hay W, Klein C, Langrock U, Lipinski M, Ricken W, Söding E, Stein R, Swientek O (2003) The Greenland-Norwegian Seaway: a key for understanding late jurassic to early Cretaceous paleoenvironments. Paleoceanography 18:1010. doi:10.1029/2001PA000625

90. NAD (1997) Nansen Arctic drilling implementation plan. Report of "Nansen Arctic drilling program implementation plan workshop", Arctic and Antarctic Research Institute, St. Petersburg, Russia, 14-15 October 1996, Joint Oceanographic Institutions, Washington, DC, p 50

91. Niessen F, Hong JK, Hegewald A, Matthiessen J, Stein R, Kim H, Kim S, Jensen L, Jokat W, Nam S-I, Kang S-H (2013) Repeated Pleistocene glaciation of the East Siberian Continental Margin. Nat Geosci 11(08):2013. doi:10.1038/NGEO1904

92. Ogawa Y, Takahashi K, Yamanaka T, Onodera J (2009) Significance of euxinic condition in the middle Eocene paleo-Arctic basin: a geochemical study on the IODP Arctic coring expedition 302 sediments. Earth Planet Sci Lett 285:190-197

93. O'Regan M (2011) Late Cenozoic Paleoceanography of the Central Arctic Ocean. IOP Conf Ser Earth Environ Sci. doi:10. 1088/1755-1315/14/1/012002 
94. O'Regan M, King J, Backman J, Jakobsson M, Pälike H, Moran K, Heil C, Sakamoto T, Cronin T, Jordan R (2008) Constraints on the Pleistocene chronology of sediments from the Lomonosov Ridge. Paleoceanography 23, PA1S19

95. Onodera J, Takahashi K (2009) Middle Eocene ebridians from the central Arctic Basin. Micropaleontology 55:187-208

96. Onodera J, Takahashi K (2009) Taxonomy and biostratigraphy of middle Eocene silicoflagellates in the central Arctic Basin. Micropaleontology 55:209-248

97. Onodera J, Takahashi K, Jordan RW (2008) Eocene silicoflagellate and ebridian paleoceanography in the central Arctic Ocean. Paleoceanography 23, PA1S15, pp 1-9. doi:10.1029/ 2007PA001474

98. Pagani M, Pedentchouk N, Huber M, Sluijs A, Schouten S, Brinkhuis H, Sinninghe Damsté JS, Dickens GR, The IODP Expedition 302 Scientists (2006) The Arctic's hydrologic response to global warming during the Palaeocene-Eocene thermal maximum. Nature 442:671-675

99. Pälike H, Spofforth DJA, O'Regan M, Gattacecca J (2008) Orbital scale variations and timescales from the Arctic Ocean. Paleoceanography 23, PA1S10, pp 1-13. doi:10.1029/ 2007PA001490

100. Poirier A, Hillaire-Marcel C (2009) Os-isotope insights into major environmental changes of the Arctic Ocean during the Cenozoic. Geophys Res Lett 36:L11602. doi:10.1029/ 2009GL037422

101. Poirier A, Hillaire-Marcel C (2011) Improved Os-isotope stratigraphy of the Arctic Ocean. Geophys Res Lett. doi:10. 1029/2011GL047953

102. Rachor E (ed.) (1997) Scientific cruise report of the Arctic Expedition ARK-XI/1 of RV "Polarstern" in 1995. Rep Pol Res 226:157

103. Rai V, Rai AK (1998) Growth behaviour of Azolla pinnata at various salinity levels and induction of high salt tolerance. Plant Soil 206:79-84

104. Röhl U, Bralower TJ, Norris G, Wefer G (2000) A new chronology for the late Paleocene thermal maximum and its environmental implications. Geology 28:927-930

105. Sangiorgi F, Brumsack H-J, Willard DA, Schouten S, Stickley C, O'Regan M, Reichart G-J, Sinninghe Damsté JS, Brinkhuis H (2008a) A 26 million year gap in the central Arctic record at the greenhouse-icehouse transition: Looking for clues. Paleoceanography 23, PA1S04, pp 1-13. doi:10.1029/2007PA001477

106. Sangiorgi F, van Soelen EE, Spofforth DAJ, Pälike H, Stickley C, St. John K, Koç N, Schouten S, Sinninghe Damsté JS, Brinkhuis H (2008b) Cyclicity in the middle Eocene central Arctic Ocean sediment record: Orbital forcing and environmental response. Paleoceanography 23, PA1S08, pp 1-14. doi:10.1029/2007PA001487

107. Sangiorgi F, Brinkhuis H, Damassa SP (2009) Arcticacysta: a new organic-walled dinoflagellate cyst genus from the early Miocene? of the central Arctic Ocean. Micropaleontology $55: 249-258$

108. Schauer U (ed.) (2008) The expedition ARKXXII-2 of the Research Vessel "Polarstern" in 2007-a contribution to the international polar year 2007/08. Rep Pol Mar Res 579

109. Schauer U (ed.) (2012) The expedition of the research vessel "Polarstern" to the Arctic in 2011 (ARK-XXVI/3-Trans Arc). Rep Pol Mar Res 649

110. Schytt V, Boström K, Hjort C (1981) Geoscience during the Ymer-80 expedition to the Arctic. Geol Fören Stockh Förh 103:109-119

111. Serreze MC, Holland MM, Stroeve J (2007) Perspectives on the Arctic's shrinking sea-ice cover. Science 315:1533-1536

112. Setoyama E, Kaminiski MA, Tyszka J (2011) Campanian agglutinated foraminifera from the Lomonosov Ridge, IODP
Expedition 302, ACEX, in the paleoceanographic context oft he Arctic Ocean. Micropaleontology 57:507-530

113. Shackleton NJ, Kennett JP (1975) Paleotemperature history of the Cenozoic and the initiation of Antarctic glaciation: oxygen and carbon isotope analysis in DSDP Sites 277, 279, and 281. Initial Rep Deep Sea Drill Proj 29:743-755

114. Shellito CJ, Sloan LC, Huber M (2003) Climate model sensitivity to atmospheric $\mathrm{CO} 2$ levels in the early-middle Paleogene. Palaeogeogr Palaeoclimatol Palaeoecol 193:113-123

115. Sinninghe Damsté JS, Wakeham SG, Kohnen MEL, Hayes JM, de Leeuw JW (1993) A 6000-year sedimentary molecular record of chemocline excursions in the Black Sea. Nature 362:827-829

116. Sluijs A, Schouten S, Pagani M, Woltering M, Brinkhuis H, Damsté JSS, Dickens GR, Huber M, Reichart G-J, Stein R, Matthiessen J, Lourens LJ, Pedentchouk N, Backman J, Moran K, The Expedition 302 Scientists (2006) Subtropical Arctic Ocean temperatures during the Palaeocene/Eocene thermal maximum. Nature 441:610-613

117. Sluijs A, Röhl U, Schouten S, Brumsack H-J, Sangiorgi F, Sinninghe Damsté JS, Brinkhuis H (2008) Arctic late Paleocene-early Eocene paleoenvironments with special emphasis on the Paleocene-Eocene thermal maximum (Lomonosov Ridge, Integrated Ocean Drilling Program Expedition 302). Paleoceanography. doi:10.1029/2007PA001495

118. Speelman EN, Reichart G-J, de Leeuw JW, Rijpstra WIC, Sinninghe Damsté JS (2009) Biomarker lipids of the freshwater fern Azolla and its fossil counterpart from the Eocene Arctic Ocean. Org Geochem 40:628-637

119. Spreen G, Kaleschke L, Heygster G (2008) Sea ice remote sensing using AMSR-E $89 \mathrm{GHz}$ channels. J Geophys Res 113:C02S03. doi:10.1029/2005JC003384

120. Spofforth DJA, Pälike H, Green D (2008) Paleogene record of elemental concentrations from the Arctic Ocean obtained by XRF analyses. Paleoceanography 23, PA1S09, pp 1-13. doi:10. 1029/2007PA001489

121. St. John K (2008) Cenozoic ice-rafting history of the Central Arctic Ocean: Terrigenous sands on the Lomonosov Ridge. Paleoceanography. doi:10.1029/2007PA001483

122. Stein R (ed.) (2005) Scientific cruise report of the Arctic Expedition ARK-XX/3 of RV "Polarstern" in 2004: fram strait, Yermak Plateau and East Greenland continental margin. Reps Pol Mar Res 517

123. Stein R (ed.) (2015) The expedition PS87 of the research vessel "Polarstern" to the Arctic in 2014. Rep Pol Mar Res 688

124. Stein R (2007) Upper cretaceous/lower tertiary black shales near the North Pole: organic-carbon origin and source-rock potential. Mar Petrol Geol 24:67-73

125. Stein R (2008) Arctic Ocean sediments: processes, proxies, and palaeoenvironment. Dev Mar Geol 2:587

126. Stein R (2011) The great challenges in Arctic Ocean paleoceanography. IOP Conf Ser Earth Environ Sci. doi:10.1088/ 1755-1315/14/1/012001

127. Stein R, Fahl K (eds.) (1997) Scientific cruise report oft he Arctic expedition ARK-XIII/2 of RV "Polarstern" in 1997. Rep Pol Res 255

128. Stein R, Boucsein B, Meyer H (2006) Anoxia and high primary production in the Paleogene central Arctic Ocean: first detailed records from Lomonosov Ridge. Geophys Res Lett 33:L18606. doi:10.1029/2006GL026776

129. Stein R, Backman J, Moran K (2007) The Arctic Coring Expedition: a breakthrough in Arctic Ocean geoscientific research. Touch Briefing: Exploration and Production-Oil and Gas Review 2007, pp 47-49

130. Stein R, Jokat W, Brinkhuis H, Clarke L, Coakley B, Jakobsson M, Matthiessen J, O’Regan M, Stickley C, St. John K, Weigelt E (2013) Arctic Ocean Paleoceanography: towards a continuous 
cenozoic record from a Greenhouse to an Icehouse World (ACEX2). IODP Proposal 708. http://www.iodp.org/expeditions

131. Stein R, Weller P, Backman J, Brinkhuis H, Moran K, Pälike H (2014) Cenozoic Arctic Ocean Climate History: some highlights from the IODP Arctic Coring Expedition (ACEX). In: Stein R, Blackman D, Inagaki F, Larsen H.-C (eds.), Earth and life processes discovered from Subseafloor Environment-A decade of science achieved by the Integrated Ocean Drilling Program (IODP), Series developments in marine geology, Vol. 7, Elsevier Amsterdam/New York, pp 259-293

132. Stickley CE, St. John K, Koc N, Jordan RW, Passchier S, Pearce RB, Kearns LE (2009) Evidence for middle Eocene Arctic sea ice from diatoms and ice-rafted debris. Nature 460:376-380

133. Stocker T, Dahe Q, Plattner G-K, Tignor MMB, Allen SK, Boschung J, Nauels A, Xia Y, Bex V, Midgley PM (2013) Climate change 2013, the physical science basis, intergovernmental panel on climate change (IPCC). Cambridge University Press, New York

134. Stroeve JC, Holland MM, Meier W, Scambos T, Serreze M (2007) Arctic sea ice decline: faster than forecast. Geophys Res Lett 34:L09501

135. Stroeve JC, Serreze MC, Holland MM, Kay JE, Malanik J, Barrett AP (2012) The Arctic's rapidly shrinking sea ice cover: a research synthesis. Clim Change 110:1005-1027

136. Suto I, Jordan RW, Watanabe M (2009) Taxonomy of middle Eocene diatom resting spores and their allied taxa from the central Arctic Basin. Micropaleontology 55:259-312

137. Thiede J (ed.) (1988) Scientific cruise report of Arctic Expedition ARK-IV/3 1987. Rep Pol Res 43, p 237

138. Thiede J (ed.) (2002) POLARSTERN ARKTIS XVII/2 cruise report: AMORE 2001 (Arctic Mid-Ocean Ridge Expedition). Reps Pol Mar Res 421

139. Thiede J, NAD Science Committee (1992) The Arctic Ocean record: key to global change (Initial Science Plan). Polarforschung 61(1): 102

140. Thiede J, Clark DL, Hermann Y (1990) Late Mesozoic and Cenozoic paleoceanography of the northern polar oceans. Geol North Am Arctic Ocean Reg 50:427-458

141. Thiede J, Winkler A, Wolf-Welling T, Eldholm O, Myhre A, Baumann K.-H, Henrich R, Stein R (1998) Late Cenozoic history of the Polar North Atlantic: results from Ocean Drilling. In: Elverhøi A, et al. (eds.), Glacial and Oceanic History of the Polar North Atlantic Margins. Quat Sci Rev 17, 185-208

142. Tindall J, Flecker R, Valdes P, Schmidt DN, Markwick P, Harris $\mathrm{J}$ (2010) Modelling the oxygen isotope distributionof ancient seawater using a coupled ocean-atmosphere GCM: implications for reconstructing early Eocene climate. Earth Planet Sci Lett 292:265-273

143. Tremblay L-B, Schmidt GA, Pfirman S, Newton R, Derepentigny $\mathrm{P}$ (2015) Is ice-rafted sediment in a North Pole marine record evidence of perennial sea-ice cover? Phil Trans Roy Soc A 373:20140168. doi:10.1098/rsta.2014.0168

144. Tripati A, Elderfield H (2005) Deep-sea temperature and circulation changes at the Paleocene-Eocene thermal maximum. Science 308:1894-1898

145. Tripati AK, Eagle RA, Morton A, Dowdeswell JA, Atkinson KL, Bahé Y, Dawber CF, Khadun E, Shaw RMH, Shorttle O, Thanabalasundaram L (2008) Evidence for glaciation in the Northern Hemisphere back to $44 \mathrm{Ma}$ from ice-rafted debris in the Greenland Sea. Earth Plan Sci Lett 265:112-122

146. Tripati A, Zachos J, Marincovich L Jr, Bice K (2001) Late Paleocene Arctic coastal climate inferred from molluscan stable and radiogenic isotope ratios. Palaeogeogr Palaeoclim Palaeoecol 170:101-113

147. Waddell LM, Moore TC (2008) Salinity of the Eocene Arctic Ocean from oxygen isotope analysis of fish bone carbonate. Paleoceanography 23, PA1S12, pp 1-14. doi:10.1029/ 2007PA001451

148. Weigelt E, Jokat W, Franke D (2014) Seismostratigraphy of the Siberian sector of the Arctic Ocean and adjacent Laptev Sea Shelf. J Geophys Res Solid Earth 119:5275-5289

149. Weijers JWH, Schouten S, Sluijs A, Brinkhuis H, Sinninghe Damsté JS (2007) Warm Arctic continents during the Palaeocene-Eocene thermal maximum. Earth Planet Sci Lett 261:230-238

150. Weller P, Stein R (2008) Paleogene biomarker records from the central Arctic Ocean (IODP Expedition 302): Organic-carbon sources, anoxia, and sea-surface temperature. Paleoceanography 23, PA1S17. doi:10.1029/2007PA001472

151. Wheeler PA (1997) 1994 Arctic Ocean section. Deep Sea Res II 44(8):1483-1757

152. Winkler A, Wolf-Welling TCW, Stattegger K, Thiede J (2002) Clay mineral sedimentation in high northern latitude deep-sea basins since the middle Miocene (ODP Leg 151, NAAG). Int J Earth Sci 91(1):133-148

153. Wolf TCW, Thiede $\mathbf{J}$ (1991) History of terrigenous sedimentation during the past 10 m.y. in the North Atlantic (ODP Legs 104, 105, and DSDP 81). Mar Geol 101:83-102

154. Wüst G, Brögmus W (1955) Ozeanographische Ergebnisse einer Untersuchungsfahrt mit Forschungskutter "Südfall" durch die Ostsee Juni/Juli 1954 (anlässlich der totalen Sonnenfinsternis auf Öland). Kieler Meeresf 11:3-21

155. Zachos J, Pagani M, Sloan L, Thomas E, Billups K (2001) Trends, rhythms, and aberrations in global climate $65 \mathrm{Ma}$ to present. Science 292:693-868

156. Zachos JC, Dickens GR, Zeebe RE (2008) An early Cenozoic perspective on greenhouse warming and carbon-cycle dynamics. Nature 451:281-283 